\title{
Effect of SMS on Nudging Young People's College-Going Decisions and Behaviors: Evidence from a College Access Program in the United States
}

\author{
Hans Walter Cabra Hernandez ${ }^{1}$
}

\begin{abstract}
This study looked at the effect of SMS on nudging students to navigate postsecondary education in a rural area in the United States. The research sought to answer two questions; 1) how are students' needs being met through the SMS service? (e.g., What are students most concerned about when they text?) and 2) to what extent are the SMS able to cultivate self-efficacy skills among students? (e.g., Are the nudges contributing to develop those skills? What evidence do we have about this?). To answer these questions, 3,660 SMS that were sent from students to program staff from a college access program between April 2019 and June 2020 were analyzed. This was the first study of its kind that looked into SMS data from a qualitative perspective. Thematic analysis and discourse analysis were used as the primary tools for exploring the content and meaning of the messages. While thematic analysis was used to identify students' needs in relation to the services provided by the college access program, discourse analysis helped us understand how students experienced higher education and the challenges they faced.
\end{abstract}

\section{Introduction}

One of the assumptions of the neoclassical economic model is that people make rational choices because they have rational preferences (Thaler \& Sunstein, 2009; Banerjee \& Duflo, 2011). Rational preferences, the model suggests, are highly influenced by people's upbringing and social capital. This means that someone's rational preferences could be someone else's irrational preferences. For instance, a person who loves fashion could prefer to allocate $80 \%$ of her or his earnings towards clothes and only $20 \%$ towards food, health or education, or vice versa. While this is not wrong (given it is a personal choice), it is worth asking whether people would make the same choices if their upbringing or social capital were identical. Currently, there is no research for or against this position. This is because humans are extremely complex creatures and predicting their behavior is not a simple task. However, one element that can contribute to understanding human behavior is information. Information helps us to comprehend how people live and why they behave in certain ways or make specific decisions. Moreover, having information about an issue allows people to widen their choices. This suggests that when people have information, they can make knowledgeable decisions. However, in real life scenarios, there are information asymmetries; not everyone has access to the same information and on a timely manner. This means that, even when information is available, it may not be accessible for everyone. This, in turn, can be detrimental to how global issues are addressed, including poverty and inequity because it does not give clear picture of people's real preferences and choices. That is why, for example, in some developing countries educating young girls is still a taboo (World Development Report, 2018) or why money is not an accurate indicator to measure child poverty (Poverty and Shared Prosperity, 2018).

Nonetheless, the rise in the use of technology for knowledge production and communication indicates that information is available and accessible, providing a solution to the problem of information asymmetry. The 2016 World Development Report states that "on average, 8 in 10 individuals in the developing world own a mobile phone, and the number is steadily rising. Even among the bottom fifth of the population, 70\% own a mobile phone" (World Development Report, $2016 \mathrm{p}$. 6). This suggests that using information technologies to improve day-to-day decision making is possible. Indeed, SMS could be considered an option to solve the information asymmetry problem because more people (regardless of their background and social capital) could have access to it. In fact, a new body of research on the use of SMS messaging to improve decision making has gradually gained momentum. These interventions are based on the assumption that by giving people accurate information about a particular issue of interest (e.g., health, education, politics, the environment, etc.) or providing specific incentives, they will make better decisions (as opposed to the decisions they would make in the absence of information or incentives). Renowned behavioral economists Thaler \& Sunstein (2009) refer to the outcome of this relationship as a "nudge". According to Thaler \& Sunstein (2009), nudges are used to motivate behavioral change by offering people more information about their preferences.

Therefore, SMS can be considered 'nudges' because they are intended to help people make informed decisions. SMS interventions can be divided into two groups: private and public.

\footnotetext{
${ }^{1}$ Corresponding author. PhD candidate in Educational Leadership and Policy Studies, University of Vermont. Email: hcabrahe@uvm.edu 
In the private sector, most applied research on the use of SMS has been tailored to increase the number of customers (fidelity to a particular brand or product), consumer choices and to improve consumer experience (World Development Report, 2016). As such, most interventions have been used to nudge people to change their preferences (e.g., buy more of a product, switch to another product, etc.).

In the public sector, the majority of studies on the use of SMS have been conducted in health, education and community participation (e.g., political campaigns, youth activism, etc.) (Bird et al., 2019). In relation to health, SMS interventions have been used to promote health care practices among aging populations (Jenaro et al., 2016; García-Viola, 2019), foster health care practices during pregnancy (Velez et al., 2017), and improve nutrition outcomes among low-income children (Gutiérrez et al., 2018). In relation to community participation, SMS campaigns have been used to increase civic engagement in social policy issues. One example is the use of SMS to persuade young people to recycle and to teach them how to do it (Buil-Cosiales et al., 2014). In relation to education, SMS interventions have been tailored to assess student's engagement (Vale et al., 2015), improve reading proficiency among pre-schoolers (York \& Loeb, 2014), assist instruction in the teaching and learning of foreign languages (Gutiérrez-Colon Plana et al., 2012), support training practices in first aid courses (Carrillo-Larco et al., 2015), and nudge college enrollment and persistence among lowincome students (Castleman et al., 2014; Castleman \& Page, 2015).

The conclusions of this body of research point to the same direction; SMS interventions can motivate (or nudge) behavioral change. According to research, this is due to the fact that messages not only provide information about a particular issue, but also persuade people to take specific actions in order to improve health, social and education outcomes (e.g., develop healthy eating habits, reduce malnutrition rates, increase civic engagement, increase college enrollment, etc.).This implies that SMS also have the potential to help people cultivate skills. Research on social emotional learning skills indicates, for example, that self-efficacy (a soft skill highly associated with task performance and a good predictor of success) is cultivated when people are exposed to challenging situations and they are able to overcome such challenges (Kankaraš \& Suarez-Alvarez, 2018). Behavioral change can certainly bring a lot of challenges to people because it entails unlearning old habits or learning new skills (Segura, 2004; Araya et al., 2007), which is not easy. Because self-efficacy has to do with task performance, growth mindset, goal setting and perseverance (Kankaraš \& Suarez-Alvarez, 2018), it can be a great skill for people who want to change certain behaviors (e.g., develop study habits). Hence, if SMS are intended to nudge behavioral change and correct for information asymmetries, it is possible that they do so by fostering soft skills such as self-efficacy.

College access programs across the United States have been designed to increase access to higher education among lowincome students. Some of these programs provide mentoring services to students and well as financial incentives to enroll such as scholarships. Other programs have also implemented additional services such as SMS to nudge students' collegegoing decisions. The college access program that this paper examines has been using SMS to communicate with students and to inform them about different services that they are eligible for such as book money, completing the Free Application for Federal Student Aid (FAFSA) to determine federal aid eligibility, information about summer class funding, emergency funds for students in financial difficulties, registering for orientation, reminders about meeting with academic advisor and using tutoring services, and reach out messages. Text messages are sent in various forms throughout the year: pre-program scripted reminders, general information messages, and personalized messages. The messages allow staff and students to have one-on-one exchanges following scripted messages and to initiate unplanned communications as needed.

Since the college access program began using SMS, it has only been able to report general outcomes. Also, due to the high volume of information contained in each dataset (more than 32,000 texts per cohort), reports have been done primarily on a quantitative basis. Hence, only high-level performance indicators have been reported (e.g., number of SMS sent to students, percentage of students engaged with SMS, number of students who opt out from the messaging service, etc.). Although the program has been subject to internal evaluations, none of them have looked into the SMS communication between students and program staff. Analyzing these messages would be of great benefit for the program because they contain valuable information about students' challenges and experiences navigating postsecondary education. For example, the messages could inform program staff of specific bottlenecks that deter students from accessing services. Additionally, the analysis will contribute to the body of research about the use of SMS interventions to increase college enrolment among low-income students.

This study looks at the effect of SMS on nudging students to navigate the higher education system in a rural state in the United States. This research seeks to answer two questions; 1) how are students' needs being met through the SMS service? (e.g., What are students most concerned about when they text? How is the program responding to those concerns?) and 2) to what extent are the SMS able to cultivate self-efficacy skills among students? (e.g., Are the nudges 
contributing to develop those skills? What evidence do we have about this?). This is the first study that will look into SMS data from a qualitative perspective. This will facilitate a closer look at the barriers young people face when deciding whether to attend college and the difficulties they encounter once enrolled. To do this, an analysis will be undertaken of the SMS sent by students between April 2019 and June 2020 using thematic analysis and discourse analysis techniques. The study is organized in 4 parts, as follows. Part 1 consists of the methods used for addressing the research questions. This includes a description of the participants, data collection and data analysis processes. Part 2 presents the results. Part 3 entails a discussion of the results and a description of the limitations. Part 4 encompasses the conclusions of the study and recommendations for program improvement and future research.

\section{Part 1: Methods}

Analysis of SMS was conducted using thematic analysis and discourse analysis. Thematic analysis is a technique used to classify qualitative data (e.g., interviews, participant observation memos, storytelling descriptions, photo elicitation, etc.) by topic or theme based on the content of the data (Nowell et al., 2017). The technique is also employed to identify relationships between topics or themes. Discourse analysis is a technique used to interpret how people experience the world by exploring how they use language (written or spoken) in relation to their social context when they talk about their lived experiences (Alvesson \& Kärreman, 2011). For instance, by examining the purpose of the discourse (e.g., whether it is descriptive, argumentative, or expository etc.) and its tone (e.g., assertive, empathetic, aggressive, violent, etc.) in relation to socioeconomic and cultural disparities, it is possible to understand how and why people experience the world differently.

These techniques were selected because they are complementary to each other and therefore, allow a holistic understanding of how students engage and use SMS. While thematic analysis can be used to identify students' needs in relation to the services provided by the program, discourse analysis can offer a detailed explanation of how students experience higher education and the challenges they face. This will contribute to the understanding of whether or not SMS are effective in nudging students' college-going decision and behaviors. The following sub-sections describe the scope of the SMS intervention, the participants and explain the data collection and data analysis processes that were undertaken to explore the SMS.

\section{Intervention}

The college access program that this paper examines uses a mass texting platform (a two-way text messaging system) to communicate with students. Based on best practices and evidence-based research, messages are meant to reduce the summer melt gap by nudging students to apply to college. Nudging has occurred twofold. On the one hand, the program formed a group of professional counselors and experts in the field of higher education to help students understand the benefits of pursuing postsecondary education. This has included workshops and personal support to students and their families navigating the higher education system (e.g., estimating the cost of attending college, financial aid eligibility, etc.). Additionally, the program provides mentorship to students who choose to apply and enroll in a postsecondary education program, book money and funding for taking summer classes ${ }^{2}$.

On the other hand, the program has implemented a text messaging intervention to remind students about the information that was covered during the workshops and inform them about the process to access scholarships and program funds. While some messages are sent to all students, many of them vary slightly depending on whether the student is at a local or an out-of-state resident, and others are only sent to certain subsets of students (e.g., students who would potentially enroll in local schools). Moreover, some of the messages are "scripted" whereas some are typed and sent by staff as the need arises. These ad-hoc messages can be sent to one individual student or simultaneously to multiple students with similar needs.

Messages are sent out at different times throughout the year. In some cases, this aligns with important deadlines or events such as committing to a higher education institution, registering for orientation, or completing financial aid applications (e.g., filling out the FAFSA). In general, SMS are sent out in 3 waves; 1) preparation to attend a higher education institution (HEI), 2) general checking, and 3) preparation for second semester or new cycle (colleges vs. technical institutions). The first wave refers to the SMS messages that remind students of key aspects of enrollment (e.g., payment plans, scholarships) and dates leading up to the start of college (e.g., orientation, registration). The second wave refers to SMS that are tailored to hear from students about their experiences during their first semester in a higher education institution.

\footnotetext{
${ }^{2}$ Due to COVID-19, the program also offered additional funding for students who had financial difficulties. 
The third wave indicates SMS that remind students of minor tasks needing to be completed before the start of their second semester or new program cycle (depending on the type of higher education institution they attend). Figure 1 shows a general overview of how SMS are sent out to students throughout the year.

In each wave, messages are organized on a priority basis. For instance, during the first wave most SMS are about reaching out to students to remind them of the program and ask them about their postsecondary education plans. These messages are intended to build rapport with students and to remind them of specific deadlines prior to starting college. Following this, financial messages are sent out to remind students to check their financial aid package, apply for book money, contact the financial aid office to ask for scholarship opportunities or set up payment plans. During wave two, messages are mainly tailored to assess students' experiences during their first semester in a higher education institution (academic and connection to campus). Other messages are also sent in relation to schedule meetings with program staff and regular check-ins. Wave three consists mostly of SMS associated with renewing financial aid packages, applying for book money, and summer funding. Regular check-in messages, as well as setting up meetings with program staff, are also sent out during this wave ${ }^{3}$.

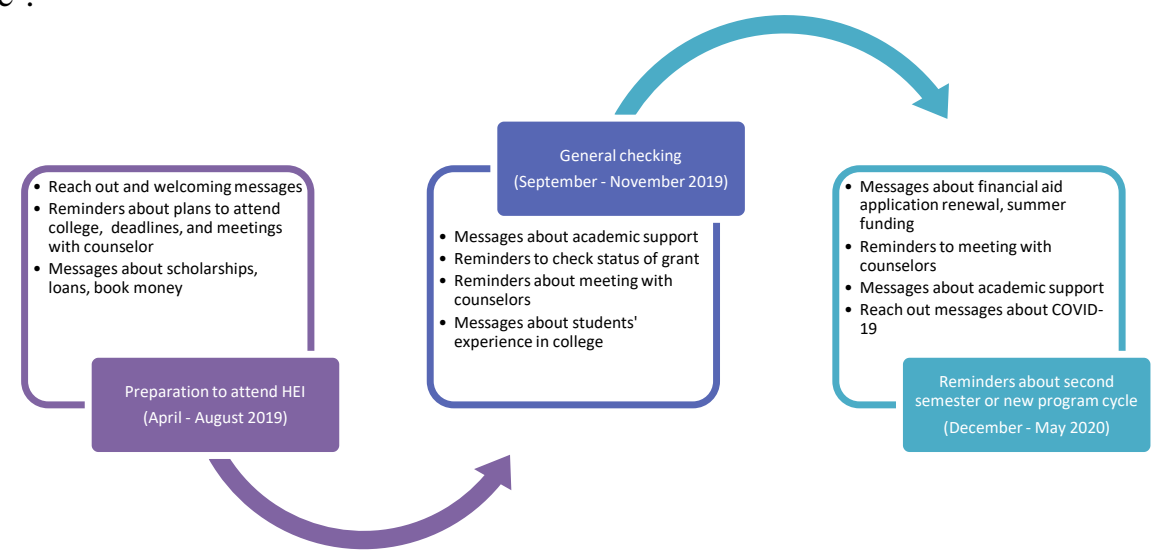

Source: Author.

Figure 1. Type of SMS messages sent to students throughout the year

As observed, financial aid messages, messages about setting up an appointment with a counselor and reach-out messages are recurrent throughout the three waves. In relation to financial aid, the literature on summer melt as well as program reports suggest that recurrence is related to the procedures associated with financial aid eligibility and the deadlines set up by colleges and universities to make tuition payments. Therefore, students have to update financial information on a regular basis in order to renew their financial aid award or estimate the cost of attendance (which will be used to set up payment plans). In regard to setting up meetings with counselors, it suggests that program staff is highly invested in helping students. With respect to reach out messages, recurrence is related to building trust and fostering relationships. According to Castleman et al. (2014) and Castleman \& Page (2015), building relationships with students is a success factor in the implementation of SMS strategies. This entails, however, active engagement from program staff as well as technical capacity to respond to students' questions and requests in a timely manner. Through the SMS strategy, the program has managed to remain highly invested in reaching out to students to help them navigate the higher education system (especially those who are first generation students).

\section{Text classification procedure}

The initial step before conducting thematic analysis and discourse analysis was to classify all the SMS by categories or topics. While it was first conceived to do it by broad categories, it became clear that some SMS contained specific information, and therefore subcategories were included. For example, while most SMS could be labeled as "financial aid", some were specific about summer funding or applying for book money. Thus, having subcategories added a layer of precision in terms of the services that students requested. Table 1 summarizes the categories and subcategories of analysis and provides a definition for what they entail (see Appendix 1 for an example of the type of SMS).

\footnotetext{
${ }^{3}$ Due to COVID-19, a lot of reach out messages and regular check-in messages were sent to ask about how students were dealing with the pandemic. Also, the program offered financial assistance to students who were experiencing financial hardships.
} 
Table 1. Text classification for the 2019-2020 SMS dataset

\begin{tabular}{|c|c|}
\hline Categories and subcategories & Definition \\
\hline Financial aid & $\begin{array}{l}\text { Messages related to the process of applying for financial aid (e.g., contacting } \\
\text { financial aid staff, loans), technical assistance completing financial information and } \\
\text { scholarship opportunities available to students }\end{array}$ \\
\hline $\begin{array}{l}\text { Financial information and reminders } \\
\text { advice }\end{array}$ & $\begin{array}{l}\text { General messages, reminders and questions about financial aid, scholarships, } \\
\text { financial aid forms (e.g., FAFSA), payment plans, tuition bills etc. }\end{array}$ \\
\hline Book money & $\begin{array}{l}\text { Messages, reminders and questions about grant money available to students to buy } \\
\text { books }\end{array}$ \\
\hline Summer class funds & $\begin{array}{l}\text { Messages, reminders and questions about grant money available to students for } \\
\text { summer classes }\end{array}$ \\
\hline Micro-grants funds & $\begin{array}{l}\text { Messages and reminders about grant money available to students for emergency relief } \\
\text { (e.g., food insecurity, COVID-19) }\end{array}$ \\
\hline Jobs/employment/work study & Messages, reminders and questions about employment or work study opportunities \\
\hline Academic support & Messages associated with navigating academic life in a higher education institution \\
\hline Tutoring/grades & $\begin{array}{l}\text { Messages, reminders, check-ins and questions about grades, accessing tutoring } \\
\text { services, academic performance as a result of COVID-19, and study tips }\end{array}$ \\
\hline Transferring schools & $\begin{array}{l}\text { Messages, check-ins and questions about transferring schools (e.g., financial and } \\
\text { academic implications) }\end{array}$ \\
\hline Orientation & Messages, reminders and questions about orientation \\
\hline $\begin{array}{l}\text { Connect with faculty, professor, } \\
\text { academic advisors, or specific other } \\
\text { academic support }\end{array}$ & $\begin{array}{l}\text { Messages, reminders and questions about relationship building with faculty, advisors } \\
\text { or other academic support staff }\end{array}$ \\
\hline Logistics & $\begin{array}{l}\text { Messages related to managerial activities. This category entails general information } \\
\text { about enrollment decisions and admission deadlines }\end{array}$ \\
\hline $\begin{array}{l}\text { Meeting reminders (e.g., with the } \\
\text { counselor) }\end{array}$ & $\begin{array}{l}\text { Messages, reminders and questions about setting up meetings with counselors } \\
\text { (program staff) to talk about different stages of the college application process }\end{array}$ \\
\hline Plans (e.g., for next semester) & $\begin{array}{l}\text { Messages, reminders, general information and updates on students' plans for after } \\
\text { high school graduation. Questions about the impact of COVID-19 in students' } \\
\text { decisions to continue their college career }\end{array}$ \\
\hline $\begin{array}{l}\text { Deadlines reminders (e.g., add/drop, } \\
\text { registration, etc.) }\end{array}$ & $\begin{array}{l}\text { Messages, reminders and questions about deadlines (e.g., registering for classes, } \\
\text { adding or dropping a class) }\end{array}$ \\
\hline Well-being & $\begin{array}{l}\text { This category encompasses messages tailored to assess students' experiences in a } \\
\text { higher education institution }\end{array}$ \\
\hline Reach out and check-in & $\begin{array}{l}\text { Messages, reminders, check-ins and questions about how students feel during their } \\
\text { first year in college. Check-in messages about the challenges related to COVID-19 }\end{array}$ \\
\hline Mental health specific & $\begin{array}{l}\text { Messages, check-ins, questions and general information about students' mental health } \\
\text { (e.g., dealing with anxiety associated with workload) }\end{array}$ \\
\hline Connection/belonging on campus & $\begin{array}{l}\text { Messages, questions and general information about students' living experiences on } \\
\text { campus or off-campus (e.g., roommates, dorms, neighborhood, etc.) }\end{array}$ \\
\hline Short answers (close-ended questions) & Messages and reminders to respond to close-ended questions (e.g., short surveys) \\
\hline Uncategorized & $\begin{array}{l}\text { Messages that do not fall into any of the other categories (e.g., thank you messages, } \\
\text { messages about holidays, emails, telephone numbers, etc.) }\end{array}$ \\
\hline Stop outs & Messages sent by students who do not want to receive any SMS messages \\
\hline
\end{tabular}

Note: Definitions were based on type of services provided to students (from program reports), content of SMS messages, literature on summer melt and conversation with program staff.

As observed, the use of subcategories in the analysis proved beneficial because it facilitated mapping out the type of services requested by students in relation to the assistance provided by the program. For instances, it became clear that students not only inquired about financial aid or academic support, but also shared their experiences with postsecondary education (e.g., feelings of anxiety and stress related to academic life or experiences with roommates and college in general). This could indicate that the SMS intervention had positive externalities on outcomes such as social emotional skills and adjustment to college life, which are key factors associated with college retention and college completion. It is important to pinpoint that one of the objectives of this process was to provide an input for future automated text classification using machine learning software applications. Thus, "key words" were included in addition to each category and subcategory so that any machine learning algorithm can perform text classification. 
Because of this, messages that did not contain specific information about a category or subcategory or answers to closeended questions or survey questions (yes/no) were classified independently as "uncategorized" and "Short answers", respectively.

\section{Participants}

This study focuses on 161 students from the high school graduating class of 2019, the most recent cohort of students to participate in a college access program in a rural state in the United States. It is important to highlight that program staff obtained consent for participation from students and their parents upon enrollment: students first joined the program and their parents consented to the program for collecting data about the services they used. Consent included collection of data for program evaluation. Students voluntarily provided their cell phone numbers before enrolling in the texting platform and were allowed to opt out of receiving texts at any time. To protect participant privacy, only de-identified data was used in this study. Program staff assigned each student a unique identification number and removed any potentially identifying information (names, phone numbers, high schools) from the dataset.

\section{Data collection}

Data on SMS were collected to fulfill reporting requirements. For this study, a subset of this information was extracted. Data was obtained by program staff via a mass texting platform. SMS are sent to students who are planning to attend college or who are in their first year of college to help them navigate the higher education system. Although the program has been using this platform to collect text messaging data since 2017, this research focuses on the data from the high school graduating class of 2019 collected between April 2019 and June 2020. The reasoning for this is because it is the most recent dataset, showing program maturation. The platform generated a spreadsheet containing information regarding SMS messages that were sent between program staff (counselors) and students and/or their parents. This information was labeled by sender, date, and type of message (e.g., scripted or personalized). Given that the research question addressed in this study is only concerned with students, parental messages were not considered. Therefore, the dataset that was analyzed for this study consisted of 21,991 texts sent between students and program staff only ${ }^{4}$. It is important to highlight that the dataset has been de-identified and therefore, this study will not cause any harm nor risks to participants.

\section{Data analysis}

Data analysis was conducted in 2 phases. Phase 1 consisted of classifying 21,991 SMS (outgoing and incoming) by categories and subcategories of analysis, and then using thematic analysis to explore the main topics or themes that were salient to students. Text classification was based on conversations with program staff in charge of the SMS strategy, revision of program reports, and existing literature on summer melt and opportunity gaps associated with access to higher education. This stage encompassed text classification analysis by categories and subcategories using Nvivo 12 and Excel. Due to the volume of texts (21,991 SMS), Nvivo was used only as an exploratory tool for coding 5 . Once this pilot coding was complete, Excel was used as the primary tool for text classification. Thematic analysis was then used to identify the distribution of SMS. This was chosen because it is a qualitative technique widely used to organize information by topic or theme and to establish relationships among them (Nowell et al., 2017). In this phase it was possible to map out the general distribution of SMS and determine the services that students were more concern about.

Phase 2 consisted of a thorough analysis of SMS by student case using discourse analysis. In this phase, SMS were analyzed in relation to students' needs. Given that students' needs are different, discourse analysis was chosen and used to interpret the meaning of each SMS in relation to the social context of each student. This technique allowed for the ability to treat each text (for each student) as part of a broad narrative, thus identifying why students text about a particular topic or theme (Alvesson \& Kärreman, 2011). Additionally, this technique was employed to identify the extent to which certain SMS contributed to fostering self-efficacy skills among students.

\footnotetext{
${ }^{4}$ SMS between parents and program staff amounted to 10,173 . Thus, total SMS sent between students, parents and program staff was 32,164 .

${ }^{5}$ Initially, it was assumed that Nvivo could be used to auto code the entire dataset given it is a feature of the software. Also, it was thought that once auto coding was completed it could be used to code datasets from previous years (patterned coding). However, this feature is only available for certain versions of the software and for specific product licenses. In addition, Nvivo has limitations associated with patterned coding for cross-sectional data. Therefore, the only available option was to code the dataset manually. However, after coding 2,000 messages, this seemed very inefficient. Hence, Excel was chosen as a primary tool for text classification (coding). After 2 weeks of intense work, the entire dataset was coded by categories and subcategories (this includes parental SMS as well).
} 
This was conducted by examining key elements of the SMS such as content and purpose (e.g., description, narration, argumentation, exposition, inquiry, etc.), tone (e.g., engaging, friendly, aggressive, indifferent, etc.), length (e.g., messages that were longer than 71 words) and occurrence (e.g., frequency of texting) ${ }^{6}$. Under this phase, it was possible to understand why some students were more engaged with the SMS strategy than others.

\section{Part 2: Results}

\section{Descriptive statistics}

The intervention reached out 161 students. Between April 2019 and June 2020, program staff sent out 18,331 SMS to those 161 students. This means that, on average, each student received 113.9 SMS. However, not all 161 students remained until the end of the intervention. For example, 19 students opted out (12\%) and $2(1.2 \%)$ never responded to any of the SMS. These students were not included in the analysis. This means that only 140 students were engaged with the messaging service at some point during the time window. Therefore, in the study period, 3,660 SMS messages were sent from 140 students to program staff. This means that, during this timeframe, students sent out, on average, 26.14 SMS. This is equivalent to almost 2 messages per student per month, which, according to the World Health Organization, is a good indicator of maturation and ownership of the intervention (WHO, 2016). The average length of SMS was 47.31 characters, with a standard deviation of 73.66. We defined a cut-off of 1 standard deviation above the mean to differentiate between short and long SMS. Thus, texts that were 120 characters or less were conceived as short, while texts that were 121 characters of more were considered long. As such, of the 3,660 SMS sent by students, 90.44\% were disproportionately short messages mostly associated with responses to survey questions, reach out messages or reminders about upcoming meetings with program staff or important deadlines. Figure 2 shows the distribution of SMS by length. This could imply that even if students were not texting a lot, they were aware of the information that program staff sent them. The fact that most of them participated in end-of-semester surveys suggests early signs of the effectiveness of the SMS intervention.

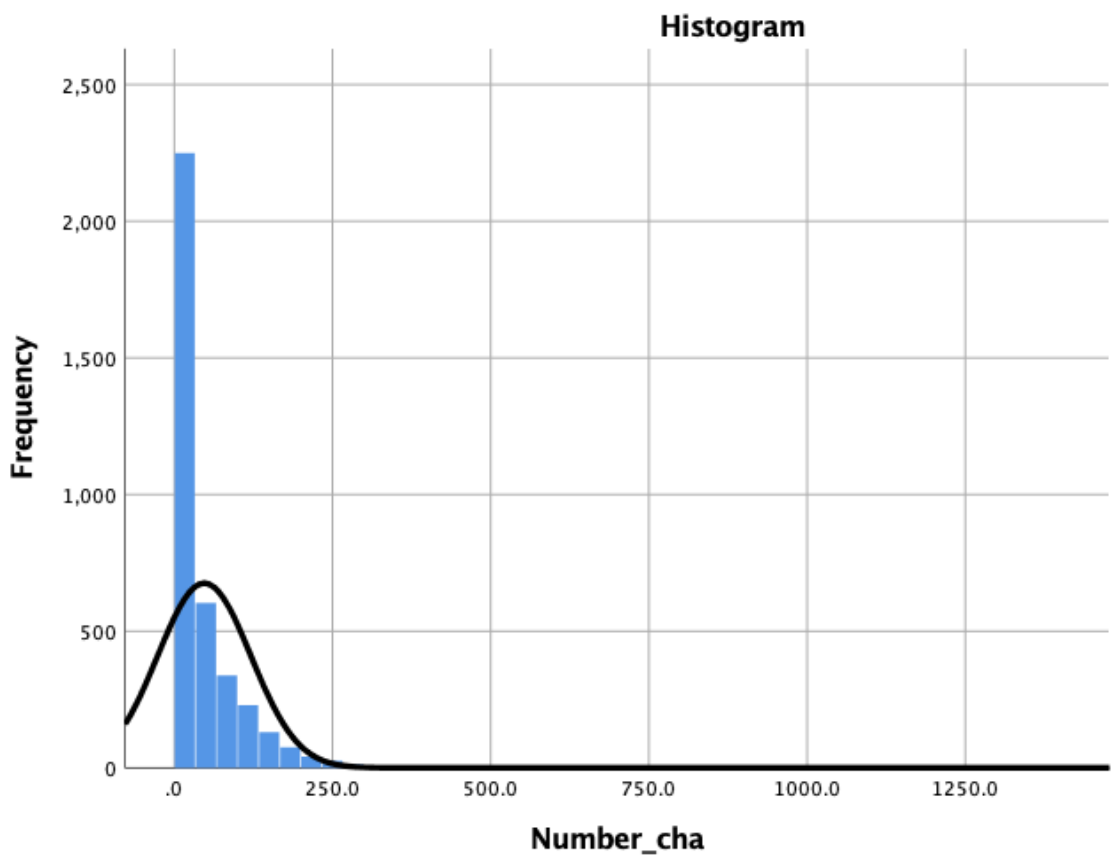

Figure 2. Distribution of SMS by length of characters

Source: Own calculations using SPSS.

Phase 1: Thematic analysis

${ }^{6}$ It is important to highlight that this process was conducted by hand-written text analysis. Doing so facilitated memo-writing, a detailed analysis of engagement and use of the SMS by students. 
Thematic analysis entailed exploring messages by topic in order to better understand the type of services that students requested or had questions about. Table 2 presents the distribution of SMS by categories and subcategories.

Table 2. Distribution of SMS messages by category and subcategory for the 2019 - 2020 dataset

\begin{tabular}{lll}
\hline Categories and subcategories & \% of SMS & Mean SMS sent by students \\
\hline Financial aid & 13.66 & 3.57 \\
\hline Financial information and reminders advice & 7.49 & 1.96 \\
Book money & 4.81 & 1.26 \\
Summer class funds & 0.79 & 0.21 \\
Micro-grants funds & 0.16 & 0.04 \\
Jobs/employment/work study & 0.41 & 0.11 \\
\hline Academic support & 5.96 & 1.56 \\
\hline Tutoring/grades & 2.92 & 0.76 \\
Transferring schools & 0.38 & 0.10 \\
Orientation & 0.74 & 0.19 \\
Connect with faculty, professor, academic & 1.89 & 0.49 \\
advisors, or specific other academic support & & \\
\hline Logistics & 11.01 & 2.85 \\
\hline Meeting reminders (e.g., with the counselor) & 4.59 & 1.20 \\
Plans (e.g., for next semester) & 5.74 & 1.47 \\
Deadlines reminders (e.g., add/drop, & 0.68 & 0.18 \\
registration, etc.) & & \\
\hline Well-being & 7.73 & 2.02 \\
\hline Reach out and check-in & 4.04 & 1.06 \\
Mental health specific (struggling, stressed, & 2.84 & 0.74 \\
freaked) & & 0.22 \\
Connection and belonging on campus & 0.85 & 8.08 \\
\hline Short answers (close-ended questions) & 30.98 & 8.06 \\
Uncategorized & 31.17 & 26.14 \\
TOTAL & 100.00 &
\end{tabular}

Note: The total number of SMS sent by students was 3,660 $(n=3,660)$, and the total number of students engaged with the intervention was 140 .

As observed, most SMS were associated with short answers to questions and uncategorized messages (30.98\% and $31.17 \%$ respectively). This means that, on average, students sent out 8.08 SMS related to short answers and 8.06 uncategorized SMS. The high response rate within these categories could be attributed to the simplicity of the format (yes/no), a financial incentive that was comprised with some of the questions (participate in a drawing to obtain extra money to buy books) or a kind gesture towards program staff given that most of the SMS were "thank you" messages. All in all, these categories revealed that students are somehow engaged with the SMS messaging service; a positive/early sign of its effectiveness.

Topics related to financial aid accounted for $13.66 \%$ of SMS; being financial information messages and applying for book money the topics that students were more concerned about. Only $0.79 \%$ of the messages under this category were about summer funding, and the remaining were about emergency grants and employment opportunities (less than $1 \%$ of SMS). This means that, on average, students sent out 3.57 SMS related to financial aid services. 
In the case of financial information, most messages were related to completing the FAFSA application, understanding financial award letters, procedures for taking loans, setting up payment plans, and updating financial information. In the case of book money, students mostly inquired about the process to obtain this grant and about the possibility of using it before the semester begins. In regard to summer funding, students asked questions about eligibility and the application process. It is worth mentioning that the highest volume of SMS was sent between August and September; crucial months for finalizing financial aid matters (e.g., loans, scholarship eligibility, payment plans, etc.). This could indicate that the SMS have a positive effect on nudging students' behaviors (e.g., curiosity and interest) in learning more about how to navigate this component of the higher education system.

The next category is logistics, which accounted for $11.01 \%$ of the total of SMS sent by students. This means that, on average, students sent out 2.85 messages related to logistics matters. Most of the messages under this category were associated with students' plans to attend college and scheduling an appointment with program staff (5.74\% and $4.59 \%$, respectively). Less than $1 \%$ were messages about registration. It is important to highlight that most students reported interest in attending local schools. This category revealed that students were highly responsive (enthusiastic) to share their plans in relation to higher education as well as to set up meetings to talk to a counselor, showing early signs of selfefficacy skills.

The next category is well-being, which accounted for $7.73 \%$ of total messages. This denotes that, on average, students sent out 2.02 well-being messages. Most of the SMS were about reaching out to counselors for help or checking in $(4.04 \%)$ while $2.84 \%$ were messages associated with students' mental health. Less than $1 \%$ were messages where students shared their feelings and experiences related to living arrangements (either on campus or off-campus). Results for this category suggest that providing a support system to help students navigate non-academic aspects of their postsecondary experience is also important for program staff. This implies commitment to students' needs, building strong relationships and fostering accountability.

The next category is academic support, which corresponded to $5.96 \%$ of total messages. This indicates that, on average, students sent out 1.56 messages that had to do with academic support. Most messages were related to grades and tutoring services $(2.92 \%)$ and connecting with faculty, advisors or peers for academic support (1.89\%). Only 1.12\% of the SMS under this category were about orientation and transferring to other schools. It is noteworthy that academic support presented the lowest volume of SMS, which was surprising given that most of postsecondary education is about navigating academic life. Therefore, it was expected that students would have a lot of questions or requests on this topic. This can be attributed to the fact that academic life is an iterative process; meaning that there is enough time to adjust and to improve performance. For instance, it takes a while for students to discover passions, form a learning community, create study habits, and access academic support services. Therefore, it is possible that students did not send as many SMS about academic support because they were currently navigating that component of their education experience. Furthermore, it is possible that accessing services related to financial aid, logistics or well-being requires more personalized support, hence the need to engage more via SMS.

\section{Phase 2: Discourse analysis}

This phase consisted of analyzing SMS by student case. This entailed considering each SMS as part of a broader social discourse. Doing so allowed us to identify not only the challenges students face when navigating postsecondary education, but also the ways in which they overcome those challenges. Two goals were set out for this process; 1) understand the efficacy of the messages in nudging students' college-going decisions, and 2) assess the level of engagement of students with the SMS strategy. Below, a description is provided of how each goal was measured and the results of this process.

\section{Goal 1. Understand the efficacy of the messages in nudging students' college-going decisions.}

To gauge efficacy, we analyzed messages where students demonstrated gradual development or mastery of self-efficacy skills. This helped us understand the extent to which the SMS intervention contributed to improve students' intrinsic motivation to accomplish goals related to higher education (Kankaraš \& Suarez-Alvarez, 2019). This was done by examining three elements of discourse: purpose, tone and length. In terms of purpose, we focused on messages where students shared opinions about their college experience (e.g., accessing tutoring services), where students had to advocate for themselves (e.g., eligibility for summer funding) or with detailed questions about financial aid ${ }^{7}$.

\footnotetext{
${ }^{7}$ I decided to focus on financial aid messages because despite the fact that program staff sent out specific messages with reminders, information and resources, this was an area where most students still faced challenges. This was corroborated by 50
} 
In relation to tone, messages where students projected friendliness, respect and proactive involvement in the communication, were identified. In terms of length, messages that contained more than 71 words were prioritized ${ }^{8}$. Given that each element assessed different parts of the discourse, relative weights (all of which would sum up to 100) were assigned. For example, it was estimated that purpose was the most important aspect of the discourse, hence its relative weight was 60. In the same way, the relative weights of tone and length were 30 and 10, respectively (see Appendix 2).

Therefore, we grouped students by level of proficiency (see Table 3). A basic proficiency level indicated that even though students reached out to program staff to learn about a specific task, there was no evidence that students attempted to complete the task or reach out for further assistance. A moderate proficiency level indicated that students would reach out and attempt to complete a task. An advanced proficiency level indicated that students engaged in thorough conversations with program staff to ask questions and advice about specific tasks. As opposed to basic and moderate selfefficacy, advanced proficiency was characterized by the completion of the task. This is confirmed by messages where students talk about how they managed to complete the task, the challenges they faced, or the lessons they learned during this process.

Table 3. Effect of SMS messages in development of self-efficacy skills among students

\begin{tabular}{|c|c|c|c|c|}
\hline $\begin{array}{l}\text { Level of } \\
\text { proficiency }\end{array}$ & Description & $\begin{array}{l}\text { Number of } \\
\text { students }\end{array}$ & $\begin{array}{l}\text { Traits in relation to } \\
\text { elements of discourse }\end{array}$ & Evidence \\
\hline Basic & $\begin{array}{l}\text { SMS messages } \\
\text { convey students' } \\
\text { interests in } \\
\text { learning about a } \\
\text { task. There is no } \\
\text { evidence that } \\
\text { students } \\
\text { attempted to } \\
\text { complete the task } \\
\text { (e.g., follow up } \\
\text { messages or new } \\
\text { conversations do } \\
\text { not address the } \\
\text { initial task) }\end{array}$ & 30 & $\begin{array}{l}\text { 1. Purpose: Text does } \\
\text { not show student's } \\
\text { intention to take action } \\
2 \text { Tone: indifferent, } \\
\text { short response, or } \\
\text { offensive } \\
\text { 3. Length: SMS is less } \\
\text { than } 40 \text { words }\end{array}$ & $\begin{array}{l}\text { "Hi I was wondering about how to register for } \\
\text { the SSS orientation" (S.75) } \\
\text { "Hello! I had a question are you still offering } \\
\text { help with money for books in the fall?" (S.15) } \\
\text { "I have not gotten an awards letter" (S.16) }\end{array}$ \\
\hline Moderate & $\begin{array}{l}\text { SMS messages } \\
\text { show how } \\
\text { students are } \\
\text { interested in } \\
\text { learning more } \\
\text { about a particular } \\
\text { task and how } \\
\text { they attempt to } \\
\text { complete it. } \\
\text { Some goals are } \\
\text { achieved }\end{array}$ & 56 & $\begin{array}{l}\text { 1. Purpose: The text } \\
\text { explains a specific } \\
\text { situation and shows } \\
\text { student's intention to } \\
\text { take action } \\
2 \text { Tone: Messages are } \\
\text { friendly and } \\
\text { respectful, but not } \\
\text { inviting } \\
\text { 3. Length: SMS is } \\
\text { between } 40-70 \text { words }\end{array}$ & $\begin{array}{l}\text { "Hey there, I was filling out the application and } \\
\text { at the beginning I had a pop up and when I } \\
\text { selected continue it submitted the Application } \\
\text { before I even started it. How can I go back in } \\
\text { and edit?" (S.119) } \\
\text { "Find at least one thing that you can do to relax } \\
\text { by yourself. For me, I always used to go for } \\
\text { swims and when I got to school, I couldn't. I } \\
\text { eventually go the pool hours and started doing } \\
\text { laps once a week and that really helped me } \\
\text { relax, stay fit, and stay focused for the week" } \\
\text { (S.64) }\end{array}$ \\
\hline Advanced & $\begin{array}{l}\text { SMS messages } \\
\text { demonstrate how } \\
\text { students } \\
\text { effectively use } \\
\text { their knowledge } \\
\text { and skills to cope }\end{array}$ & 54 & $\begin{array}{l}\text { 1. Purpose: The text } \\
\text { elucidates the ways in } \\
\text { which the student uses } \\
\text { his/her knowledge and } \\
\text { skills to address a } \\
\text { challenging situation }\end{array}$ & $\begin{array}{l}\text { "Okay I already got some of my books but my } \\
\text { school is refunding me. And putting the rest too } \\
\text { my financial aid award. However, I still have to } \\
\text { get a book that's } 130 \text { dollars so if I could know } \\
\text { how to do that it would be great I can do it }\end{array}$ \\
\hline
\end{tabular}

the high volume of SMS messages that students sent out about issues such as filling out the FAFSA application, renewing scholarships, applying for book money, setting up a payment plan, taking a loan, applying for summer funding, etc.

${ }^{8}$ SMS shorter than 70 words are difficult to read as "discourses" because they lack a clear distinction between the purpose of the text and the role of the sender. Thus, it is difficult to identify evidence of self-efficacy skills. On the contrary, SMS longer that 71 words (almost an average paragraph) provide more elaborate narratives of how students experience postsecondary education. 


\begin{tabular}{|c|c|c|c|c|}
\hline $\begin{array}{l}\text { Level of } \\
\text { proficiency }\end{array}$ & Description & $\begin{array}{l}\text { Number of } \\
\text { students }\end{array}$ & $\begin{array}{l}\text { Traits in relation to } \\
\text { elements of discourse }\end{array}$ & Evidence \\
\hline & $\begin{array}{l}\text { with challenging } \\
\text { tasks and achieve } \\
\text { specific goals }\end{array}$ & & $\begin{array}{l}\text { or to achieve a specific } \\
\text { goal } \\
2 \text { Tone: SMS is } \\
\text { friendly, respectful } \\
\text { and inviting. This } \\
\text { provides some } \\
\text { evidence of active } \\
\text { participation in the } \\
\text { conversation } \\
\text { 3. Length: SMS is } \\
\text { longer than } 71 \text { words. } \\
\text { This facilitates a } \\
\text { thorough } \\
\text { understanding of } \\
\text { students' needs vs. } \\
\text { social context }\end{array}$ & $\begin{array}{l}\text { tomorrow with my mother! Thank you so so } \\
\text { much!" (S.57) } \\
\text { "What I learned from Student Financial Aid: } \\
\text { The bill at the moment is a work in progress. } \\
\text { Everything is still being generated and the final } \\
\text { bill will come out on the 13th of December. I was } \\
\text { concerned about the coat because I thought the } \\
\text { bill per semester was going to be smaller than it } \\
\text { actually is based on the information I received } \\
\text { about my bill prior to coming to [college name]. } \\
\text { However, after having gone over my bill with } \\
\text { student financial services, I learned what } \\
\text { actually went into bill, such as classes, tuition, } \\
\text { room/ board, and meal plan. In addition I } \\
\text { learned that Ineed to get more aid and apply for } \\
\text { more scholarships for future semesters so it is } \\
\text { not as expensive" (S.26) } \\
\text { "I've gotten into [college name] which I know is } \\
\text { an expensive school. I was hoping to meet with } \\
\text { you as soon as possible in order to get an idea } \\
\text { of which schools to go to for accepted students } \\
\text { day and when to check them out. I'm on a tight } \\
\text { timeline if deposits are due by the lst which I } \\
\text { plan to submit the } 30 t h \text { once I've gotten my final } \\
\text { decision. I really enjoyed [college name] this } \\
\text { weekend" (S.97) } \\
\text { "I have been to the tutoring center twice now } \\
\text { and both times seemed to help. Chemistry has } \\
\text { been hard for me and getting someone to sit } \\
\text { down and explain things to me is really helpful. } \\
\text { They were both super nice too. The overall } \\
\text { experience was nice and helped with my } \\
\text { understanding of certain aspects of chemistry" } \\
\text { (S.108) }\end{array}$ \\
\hline
\end{tabular}

Note: Total number of students considered for the discourse analysis $=140(\mathrm{n}=140) .19$ students stopped out from the SMS service and 2 never responded to SMS. These students were not included in the analysis.

As observed, the difference between basic and moderate-advanced proficient students is noteworthy. Students at the basic end of the self-efficacy skills spectrum only asked general questions or described a specific challenging situation (e.g., loans, employment, etc.) without positioning themselves as problem-solvers. Moreover, some students asked questions that seem to have been covered in workshops or general information reminders sent from program staff. This suggests that students either did not pay attention to the messages or that they struggled to understand their counselor's advice. This was corroborated by the fact that there was no evidence from the SMS exchanges with program staff that students took any action to overcome those challenges or to solve their questions (see Appendix 3 for an example). As such, most of these students stopped responding to SMS until program staff sent out reach-out messages to assess students' wellbeing due to COVID-19. Under this special circumstance, some of these students texted back, others did not. Most of the responses, however, did not meet the criteria to qualify as signs of moderate or advance self-efficacy skills.

On the contrary, students in the moderate and advanced self-efficacy skills spectrum not only asked questions and described challenging situations that they were facing, but they also elaborated a narrative to explain how and why they would overcome those challenges. 
In some cases, students also shared their experiences overcoming those challenges and even offered help to other students. This illustrates that they were not only aware of the support system available to them, but that they understood their leadership role in the process. A point worth noticing is that most of these students seem to come from high poverty backgrounds. While it is true that the program targets low-income students, the students who displayed moderate to high self-efficacy skills were students who openly voiced going through hardships. This is interesting because it suggests that self-efficacy skills germinate from adversity; that is to say, as a result of dealing with challenging situations. Kankaraš \& Suarez-Alvarez (2018) provide support to this hypothesis when they state that "people with high self-efficacy believe that they can deal with most problems that arise and therefore, do not try and avoid situations they perceive as being difficult" (Kankaraš \& Suarez-Alvarez, 2018 p. 42). This implies that there could be a relationship between poverty and developing self-efficacy skills.

This is exactly what we identified from the discourse analysis: most students who exhibited moderate or advanced selfefficacy skills were persistently inquiring about financial resources and showing program staff that they were invested in using their advice for problem-solving. For example, students who requested information about summer funding or micro-credit grants also messaged program staff to explain why they qualified to receive the grant and how it would benefit them. Similarly, students who inquired about specific aspects of the financial aid process such as updating family income or renewing scholarships, were constantly reaching out to program staff to confirm the status of the process. The same was true for students who shared their experiences with tutoring services, extracurricular activities, or coping with mental health issues. This suggests that perhaps SMS have helped students cultivate self-efficacy skills as they navigate the postsecondary education system. In a nutshell, the SMS strategy has nudged them to start a professional career (see Appendix 4 for an example).

Goal 2. Assess students' engagement with the SMS strategy.

To measure engagement, 2 variables were considered: 1) consistency of messaging (frequency) and 2) categories/subcategories of the messages. In relation to consistency, attention was paid to the frequency with which students sent SMS during the intervention. If students sent out messages every two or three months or if students sent out messages only during one semester or one specific month, they were considered inconsistent. Students who sent out at least one message per month were considered to be fairly consistent. Students who sent out more than two messages per month were considered very consistent.

In terms of type of categories and subcategories, priority was given to students who sent out at least one message associated with financial aid, academic support, logistics, or well-being. This provided evidence that students were invested in communicating with program staff and not merely answering survey questions or responding to greeting messages (e.g., replying "thank you" to a message wishing students a relaxing winter break). This, in turn, helped the assessment of student engagement within the SMS strategy. Table 4 summarizes the results of this process.

Table 4. Students' engagement level with the SMS strategy

\begin{tabular}{|c|c|c|c|c|}
\hline $\begin{array}{l}\text { Level of } \\
\text { engagement }\end{array}$ & Description & $\begin{array}{l}\text { Number } \\
\text { students }\end{array}$ & $\begin{array}{l}\text { Characteristics of SMS } \\
\text { messages }\end{array}$ & Analysis \\
\hline No engagement & $\begin{array}{l}\text { Students opt out } \\
\text { from SMS } \\
\text { messaging service }\end{array}$ & $\begin{array}{l}22 \\
* \text { Unfortunately, } \\
\text { one student } \\
\text { passed away }\end{array}$ & $\begin{array}{l}\text { Straight forward message } \\
\text { labeled as "Stop" or "Stop } \\
\text { out". Sometimes students } \\
\text { sent more than one message } \\
\text { to remind program staff } \\
\text { about their decision to opt } \\
\text { out from the SMS } \\
\text { messaging service }\end{array}$ & $\begin{array}{l}\text { The percentage of SMS messages that were stop } \\
\text { outs was less than } 1 \% \text {. This is a good indicator of } \\
\text { usability and engagement. The student who } \\
\text { passed away was initially considered low- } \\
\text { engaged until her mother texted program staff in } \\
\text { June } 2020 \text { to share the tragic news. In total, only } \\
19 \text { students opted out from the SMS service }\end{array}$ \\
\hline Low & $\begin{array}{l}\text { Students send } \\
\text { between } 1 \text { and } 20 \\
\text { SMS messages }\end{array}$ & 76 & $\begin{array}{l}\text { Messages are distributed } \\
\text { between one and two } \\
\text { categories. At least one } \\
\text { message is from one } \\
\text { category. In general, low } \\
\text { engaged students send out } \\
\text { messages from the "Short } \\
\text { answers to questions" } \\
\text { category, the "logistics" } \\
\text { category }\end{array}$ & $\begin{array}{l}\text { Short answers to questions. Under this category } \\
\text { students simply responded to close-ended } \\
\text { questions (mainly surveys) Engagement was } \\
\text { motivated either by a financial incentive (e.g., } \\
\text { participating in a drawing to obtain additional } \\
\text { money for books) or by courtesy towards } \\
\text { program staff } \\
\text { Logistics. Under this category students sent } \\
\text { messages associated with 1) college plans and 2) }\end{array}$ \\
\hline
\end{tabular}


setting up a meeting with program staff (e.g., counselors)

$\begin{array}{lll}\text { Medium students } \begin{array}{l}\text { send 33 } \\ \text { between 21 and 40 } \\ \text { SMS messages }\end{array} & \begin{array}{l}\text { Messages are distributed } \\ \text { between two and three } \\ \text { categories. Generally, } \\ \text { medium engaged students }\end{array} \\ & \text { send out messages from the } \\ & \text { following categories: 1) } \\ & \text { financial aid, 2) academic } \\ & \text { support, 3) logistics. If } \\ & \text { students only send out two } \\ & \text { messages, they are most } \\ & \text { likely financial aid and } \\ & \text { logistics. Students also send } \\ & \text { "Short answers to questions } \\ & \text { messages" }\end{array}$

Financial aid. Students inquired about filling out the FAFSA application, application for book money, and summer funding. When asked about micro-grant funding or work study opportunities, students were very keen to respond or further inquire about the process associated with accessing those resources. Messages were very concise and tailored to specific aspects of the financial aid process

Academic support. Students responded to basic questions about grades. They also shared experiences with tutoring services as well as with faculty. In some cases, students gave advice to peers in topics such as studying for exams and how to approach professors. Few students asked questions about transferring to other schools. As a result of COVID-19, some students shared their experiences with online learning and the effect this had on the overall academic performance

Logistic. Students shared their college plans, information about orientation and willingness to meet with program staff (e.g., counselors)

Short answers to questions. Students responded to short answer questions

High Students send more $30 \quad$ Students send out at least
than 41 messages one message per category. Students also send "Short answers to questions messages"
Highly engaged students sent out two types of messages: 1) responses to specific questions or tasks from program staff (e.g., reminders to renew the FAFSA, instructions related to applying for book money, share experiences with academic support services, share college experience outside classrooms, etc.), and 2) detailed inquiries about certain aspects of college life

These messages were not necessarily long. On the contrary, they were very concise and resultsoriented. Hence, highly engaged students did not stop messaging until their questions were solved or until they were able to set up an appointment (by phone or in-person) with program staff In addition, highly engaged students also sent out well-being messages. In these messages, students shared how they felt about college and what they did to cope with specific challenges. Some students also sent greeting messages to program staff. This is a good indicator of strong relationships (a key success factor in the implementation of SMS strategies)

Note: Total number of students $=161(\mathrm{n}=161)$ 
As observed, most students fall at the low end of the engagement spectrum. These students sent out less than 20 SMS in the study time period. Of these messages, more than half were responses to short questions (surveys) or logistic messages (e.g., students shared where they were going to college). As such, these students had minimal communication with program staff, however, akin to the self-efficacy assessment; low engagement with the SMS platform does not necessarily mean low task performance. Medium engagement encompassed students that sent out between 21 and 40 SMS (on average, more than 2 per month). These students sent out messages from more diverse topics, for example, students in the medium category asked questions about financial aid, logistics matters (e.g., setting up a meeting with a counselor, plans to attend college), and academic support (e.g., tutoring and meeting with academic advisor). In some cases, students also sent out messages regarding well-being (e.g., general check-in or mental health messages). Most medium engaged students messaged program staff until June 2020.

Highly engaged students, on the contrary, sent out between 41 and 175 messages. There were 8 students who sent out more than 80 messages (on average, more than 5 messages per month). These students reached out to program staff with questions from all categories and elucidated a desire to learn more about specific aspects of the postsecondary education system. For instance, students asked questions about transferring to other schools and the repercussions on financial aid eligibility, status of loan payments due to COVID-19, etc. Moreover, these students responded to survey questions in a timely manner and they were diligent in setting up meetings (by phone or in-person) with program staff. Students in this category reached out to program staff to show appreciation for their work or just to check-in with them. Similar to medium engaged students, highly engaged students proved to be consistent throughout the rollout of the SMS strategy. This indicates strong commitment to program goals and development of meaningful relationships with program staff, which are key elements for successful program implementation.

\section{Part 3: Discussion and limitations}

\section{Discussion}

The results of this study suggest that SMS have a positive effect in nudging students' college-going decisions and behaviors associated with navigating postsecondary education. In terms of college-going decisions, SMS have allowed students to make informed decisions about where they want to go to college and why. For instance, messages about financial aid eligibility have nudged students to attend local schools (mainly public institutions). This is a positive outcome in relation to how the program is striving to close socioeconomic opportunity gaps in higher education. In relation to nudging behaviors to navigate postsecondary education, SMS have empowered some students to ask for help and use the resources to attain specific goals. This has resulted in the development of self-efficacy skills and gradual student engagement.

However, the majority of students only responded to survey questions or general check-in messages. Does this mean that these students were not successful? Does this imply that these students lacked self-efficacy skills? What does this say about the overall effect of the SMS strategy? From program reports and conversations with program staff, it is clear that the SMS strategy was not designed to be a requirement for student participation (something that is common in safety net programs such as conditional cash transfers). Therefore, students were not expected to respond to program staff messages. Instead, the messages that were sent out to students were meant to provide information and resources about higher education. The intrinsic expectation was that students would be aware of those resources and that they would use them, if needed. This included a standing offer of direct assistance from program staff for problem-solving issues and advising.

The fact that many students only responded to survey questions or check-in messages does not necessarily mean that those students were unsuccessful or that they lacked self-efficacy skills. Different hypotheses can be extrapolated. One explanation is that these students were already well-informed about postsecondary education and had a very strong support system (family or friends), making the transition from high school to a higher education institution. Another potential explanation is that these students had strong self-efficacy skills and relied on resources other than staff for information and support. It is also possible these students read and used the information and reminders provided through the text messages but chose not to text back. Based on the low attrition rate (only 19 students opted out of the texting service), we can assume that most students found the information from the messages helpful enough to continue receiving them, and it is likely some used the information to solve their questions. As such, it is assumed that these messages helped students be successful at navigating their postsecondary education experience.

Additionally, given that highly engaged students seemed to come from high poverty households, it is possible to suggest that that the SMS strategy has been effective at serving the most marginalized students. 
Applied research on development economics highlights that one of the most challenging elements of program evaluation or policy analysis is to prove how a policy or a program can improve the living conditions of a targeted population (Banerjee \& Duflo, 2011). This often occurs because policymakers and researchers fail to design interventions that reach the most marginalized (Banerjee \& Duflo, 2011). As such, policies or programs that seek to reduce poverty need to fully understand how poor people live in order to comprehend why they make certain choices or why they behave in a particular way (Banerjee \& Duflo, 2011). According to Banerjee \& Duflo (2011) this is the only mechanism by which it will be possible to design effective and sustainable interventions (Banerjee \& Duflo, 2011). Therefore, it seems that the SMS strategy implemented by the program has served as an instrument to close socioeconomic opportunity gaps by empowering students to navigate the higher education system.

\section{Limitations}

Given the qualitative nature of this study, we cannot infer causation nor establish a statistical relationship between SMS and student's behaviors; which is a problem of internal validity. While external validity and generalizability of results are an issue too, they are more attributable to the specific characteristics of the program. This makes difficult to assume that most of the results of this study would apply accurately to another group of students or even to another cohort within the program. For example, the fact that COVID-19 happened while conducting this study could be argued as an issue for generalizability or external validity because this semester was especially atypical. Therefore, further research needs to be conducted to solve some of these problems, including a quantitative component that analyzes variables such as socio demographic characteristics of students (e.g., income, race, gender, parents' education, etc.) and their academic performance (e.g., GPAs) in relation to texting behavior. However, it is important to pinpoint that the methods selected for this study as well as the process undertaken for data analysis, demonstrate a clear understanding of the importance of robust inquiry. Therefore, the results of this study need to be considered exploratory evidence. Using a mixed methods approach (e.g., a randomized control trial in combination with focus groups or a design thinking activity) would be a recommended next step-in order to evaluate the impact of the SMS strategy in nudging students' college-going decisions and behaviors. Doing so will inform the design and implementation of evidence-based interventions that can effectively close socioeconomic opportunity gaps associated with postsecondary education.

\section{Part 4: Conclusion}

This study shows that SMS have a positive effect on nudging students' college-going decisions and behaviors. By examining students' messages through the lenses of thematic and discourse analysis techniques, comprehension of how students interact with program staff and the challenges that they face while navigating postsecondary education was obtained. Thematic analysis helped to identify patterns in the types of messages that students typically sent out to program staff. This allowed for the ability to map services that students needed the most. For instance, services related to renewing scholarships (e.g., updating financial information), applications to additional grants and book money, funding for summer classes or setting up an appointment with program staff were salient for students.

Discourse analysis provided some understanding of why some students were highly engaged with the SMS strategy while others were not. For example, the identification that students who were either moderately or highly engaged were students who expressly communicated to program staff that they were experiencing financial hardships. Thus, this could indicate that financial hardships pushed students to use the platform more, although we cannot be sure without objective measures of student finances. Still, this corroborates the current hypothesis that SMS is effective among financially marginalized populations. A reason behind this is that most of these interventions are complemented by incentives (e.g., free medical check-ups, money, scholarships, etc.) that are highly valued by participants. Thus, there is an extrinsic motivation to participate, which in the case of SMS interventions is associated with engagement with the texting service. This is exactly what was observed in the current study; the most persistent and engaged students were usually the ones who experienced some sort of financial difficulties.

The discourse analysis component also allowed us to identify that most of the highly engaged students exhibited selfefficacy skills. For instance, we observed that highly engaged students not only asked general questions (e.g., scholarships, summer class funding, academic support, etc.); they also showed program staff how they managed to overcome challenges (e.g., renewing the FASFA, accessing tutoring services, etc.). This suggests that the SMS strategy has been effective at motivating students to take action (especially those who come from high poverty backgrounds), which means that the nudges are empowering. This is a good indicator of the potential benefits of SMS to reduce socioeconomic opportunity gaps in access to higher education. 


\section{Recommendations}

Although it is clear that increasing student participation with the SMS strategy is not a program outcome, the findings from this study indicate that the strategy has been effective at nudging students to navigate the higher education system in a rural state in the United States. In addition, this study has shown that nudges have spurred some students to develop self-efficacy skills, which research suggests are key to healthy human development and happiness (Kankaraš \& SuarezAlvarez, 2018). Therefore, there is an opportunity to enhance student engagement so that most students can cultivate self-efficacy skills and use them to thrive in higher education settings. This could have positive effects on increasing college enrollment and persistence, thus further reducing the socioeconomic opportunity gap related to access to higher education among youth. Finally, in order to improve service delivery via SMS, it is recommended that the program considers:

\section{Including students' input when drafting SMS scripts.}

Peer-to-peer messages are highly effective because their language, tone and context are youth-oriented. Therefore, the messages can foster trust and responsiveness, which are key elements for relationship building. Moreover, including students in this process would be an opportunity for them to develop self-efficacy and leadership skills. This could be done by launching a "creativity contest" or by creating a "creative writing lab". While the first option would be driven by competition, the second one would be based on collaboration. Either of them, however, would be a good tool to foster participation. It is suggested that initiating a pilot project that includes only messages associated with well-being and academic support would be beneficial, because those are areas where students have high familiarity. This will allow gauging the strategy and making adjustments. A roll out stage will follow to include financial aid messages, logistics messages and survey questions.

\section{Classifying messages not only by category (theme or topic), but also by purpose.}

Research on the effectiveness of SMS in nudging people's behaviors suggests that people are more prone to act or respond to messages when they understand the purpose (or goal) of the message (York \& Loeb, 2014). York \& Loeb (2014) suggest a typology: messages can state FACTS, give TIPS, or incentivize GROWTH (York \& Loeb, 2014). FACT messages give general information to students. To increase effectiveness, the authors suggest that messages could be tied up with interesting statistics (e.g., Did you know that the unemployment rate for people with a college degree is only $2.8 \%$, and $5.4 \%$ for people with a high school degree? Did you know that the median usual weekly earnings for people with a college degree is $\$ 1,137$ while it is $\$ 678$ for people with a high school diploma?). TIP messages give students advice about specific tasks and remind them of specific deadlines (e.g., If you start studying ahead of time for your midterms you will not only do well, but also you will have time to relax with friends!). GROWTH messages are tailored to foster self-efficacy skills by asking students to complete specific tasks (e.g., FAFSA application, registering for classes, etc.). Therefore, this strategy entails adding another layer to the text classification process so that it includes the typology suggested by York \& Loeb (2014). Under this strategy, personalized messages will continue as needs arise. A roll out stage will follow with new cohorts of students. It is highly recommended to conduct a new study (after a year of implementation) to compare findings. This will allow to assess the effectiveness of this strategy in terms of increasing engagement.

\section{Improving software specifications from the mass texting platform to optimize data collection and data analysis.}

Current software specifications do not permit labeling of messages (in-coming and out-going) by category. This means that it is difficult to assess service delivery and conduct data analysis from the datasets that are generated by the software unless you are responsible for sending messages to students (e.g., program director or counselors). Hence, manual classification is required, which is extremely time consuming and inefficient ${ }^{9}$. Therefore, it is recommended that text classification is automated. This can be done either by extending software specifications (e.g., enhancing new features or creating new functions) or by using other software that allows to build text classification models (e.g., Python, R, etc.). The manual text classification done for this study will be a valuable input for this strategy.

\footnotetext{
${ }^{9}$ As explained before, part of this study consisted of creating categories and labeling all the SMS in the dataset. This was done manually in an Excel file and it took approximately 1 month to complete because the dataset contained over 32,000 SMS.
} 


\section{References}

Alvesson, M., Kärreman, D. (2011). Decolonizing discourse: Critical reflections on organizational discourse analysis. Human Relations, 64(9): 1121-1146. Retrieved July 17, 2020.

Araya, V., Alfaro, M., Andonegui, M. (2007). Constructivismo: origenes y perspectivas [Constructivism: origins and perspectives]. Laurus, 13(24): 76-92. Retrieved July 10, 2020. Available at https://www.redalyc.org/pdf/761/76111485004.pdf

Banerjee A., Duflo, E. (2011). Poor economics: a radical rethinking of the way to fight global poverty. New York, NY: PUBLICAFFAIRS.

Bird, K.A., Castleman, B.L., Denning, J.D., Goodman, J., Lamberton, C., Rosinger, K. (2019). "Nudging at scale: Experimental Evidence From FAFSA Completion Campaigns." National Bureau of Economic Research. Working Paper No. 26158. Retrieved May 26, 2020.

Buil-Cosiales, P., Roger-Loppacher, O., Marimon, F. (2014). The impact of SMS messages on young people's participation in recycling campaigns. Communication \& Society, 27(1): 161-182. Retrieved June 7, 2020. Available at https://revistas.unav.edu/index.php/communication-and-society/article/view/36009/30591

Carrillo-Larco, R., Shu-Yip, S., Perez-Lu, J. (2015). Aplicación académica de mensajes de texto en un curso de primeros auxilios: estudio piloto en una universidad privada de Lima, Perú [Academic application of SMS in a first aid course: pilot study at a private university in Lima, Perú]. Revista Peruana de Medicina Experimental y Salud Publica, 32(2): 278-82. Retrieved June 25, 2020. Available at https://rpmesp.ins.gob.pe/index.php/rpmesp/article/view/1620/1593

Castleman, B., Owen, L., Page, L., Stephany, B. (2014). Working paper: using text messaging to guide students on the path to college. Curry School of Education \& Frank Batten School of Leadership and Public Policy. Retrieved May 17, 2020.

Castleman, B.L., \& Page, L.C. (2015). Summer Nudging: Can Personalized Text Messages And Peer Mentor Outreach Increase College Going Among Low-Income High School Graduates? Journal of Economic Behavior and Organization, 115: 144-160.

Garcia-Viola, A. (2019). Influencia del envío de mensajes de texto al teléfono móvil en el control glucémico de la diabetes tipo 2 [Influence of sending messages to the mobile phone in the glycemic control of diabetes type 2]. Revista Española de Comunicación en Salud - RECS, 10(2): 171-178. Retrieved June 28, 2020. Available at https://erevistas.uc3m.es/index.php/RECS/article/view/4804/3587

Gutiérrez-Colon, M., Gallardo P., Grova, M. (2012). SMS as a learning tool: an experimental study. The EUROCALL Review, 20(2): 33-47. Retrieved June 8, 2020. Available at https://polipapers.upv.es/index.php/eurocall/article/view/11376

Gutiérrez, N., Medina, C., Zella M., Vera, P. (2018). Mensajes poderosos: Promoviendo el mejoramiento de la nutrición [Powerful messages: promoting nutrition improvement]. World Bank. Retrieved June 20, 2020. Available at http://documents1.worldbank.org/curated/en/209451544120087142/pdf/132740-SPANISH-WP-P158943-512-2018-16-54-6-PARAWEBMENSAJJESPODEROSOS.pdf

Jenaro, C., Flores, N., Cruz, M., Moro, L., Perez, C. (2016). Eficacia de los mensajes de texto para el cuidado de la salud en población mayor [Efficacy of SMS to promote health care in the elderly]. Gerokomos, 27(2): 42-47. Retrieved June 7, 2020. Available at http://scielo.isciii.es/pdf/geroko/v27n2/02_originales_01.pdf

Nowell, L., Norris, J., White, D., Moules, N. (2017). Thematic analysis: Striving to meet the trustworthiness criteria. International Journal of Qualitative Methods, 16: 1-13. Retrieved July 17, 2020. Available at https://journals.sagepub.com/doi/pdf/10.1177/1609406917733847

Poverty and Shared Prosperity. (2018). Piecing together the poverty puzzle. World Bank Group. Retrieved June 8, 2020. Available at https://www.worldbank.org/en/publication/poverty-and-shared-prosperity

Segura, M. (2004). El ambiente y la disciplina escolar en el conductismo y el constructivismo [Environment and school discipline in relation to behaviorism and constructivism]. Revista Electrónica Actualidades Investigativas en Educación, Universidad de Costa Rica, 5: 1-18. Retrieved July 8, 2020. Available at https://biblat.unam.mx/hevila/Actualidadesinvestigativaseneducacion/2005/vol5/noext/3.pdf

Thaler, R., Sunstein, C. (2009). Nudge: improving decisions about health, wealth, and happiness. New York, NY: Penguin Books.

Vale, O., Rivera, M., Wagner, C. (2015). SMS en el salón de clases: Usos y prácticas de estudiantes universitarios [SMS in classrooms: uses and applications among university students]. Revista International de Aprendizaje $y$ Cibersociedad, 19(2): 91-103. Retrieved June7, 2020. Available at https://cgscholar.com/bookstore/works/sms-en-el-salon-de-clases 
Vélez, C., Jaramillo, C., García, J., Barrera, C. (2017). Adaptación transcultural de mensajes de texto para autocuidado en gestantes [Transcultural adaptation of text messages to promote health for pregnant women]. Revista Investigaciones Andina, 19(34): 1813-1828. Retrieved June 7, 2020. Available at http://revia.areandina.edu.co/ojs/index.php/IA/article/view/935

World Development Report. (2016). Digital dividends. World Bank Group. Retrieved June 8, 2020. Available at https://www.worldbank.org/en/publication/wdr2016

World Development Report. (2018). Learning to realize education's promise. World Bank Group. Retrieved October 28, 2018. Available at http://www.worldbank.org/en/publication/wdr2018

World Health Organization. (2016). Monitoring and evaluating digital health interventions: A practical guide to conducting research and assessment. Retrieved July 16, 2020. Available at https://apps.who.int/iris/bitstream/handle/10665/252183/9789241511766eng.pdf;jsessionid=20E769E71EF678400590C44A2E92A39E?sequence=1

York, B., Loeb, S. (2014). One step at the time: The effects of an early literacy text messaging program for parents of pre-schoolers. National Bureau of Economic Research. Working Paper 20659. Retrieved July 3, 2020. Available at https://www.nber.org/papers/w20659.pdf

\section{Appendix 1 - Examples of SMS classified by category and subcategory (SMS sent by students)}

\begin{tabular}{|c|c|}
\hline Categories and subcategories & SMS from dataset \\
\hline \multicolumn{2}{|l|}{ Financial aid } \\
\hline $\begin{array}{l}\text { Financial information and reminders } \\
\text { advice }\end{array}$ & "How does my award get applied to my tuition payment?" \\
\hline Book money & $\begin{array}{l}\text { "I have heard about [program name] grant money towards books- would I be eligible } \\
\text { for that?" }\end{array}$ \\
\hline Summer class funds & $\begin{array}{l}\text { "I was wondering I there was any scholarships or grants I could apply to for summer } \\
\text { courses? Thank you!" }\end{array}$ \\
\hline Micro-grants funds & "How would I apply for the [program name] micro grant?" \\
\hline Jobs/employment/work study & $\begin{array}{l}\text { "I want to apply for it as a work study job. I just don't have a car so I couldn't drive } \\
\text { there. So that's the only down fall" }\end{array}$ \\
\hline Academic support & Messages associated with navigating academic life in a higher education institution \\
\hline Tutoring/grades & $\begin{array}{l}\text { "I have gone to the TA office hours for chemistry a few times, and I attend a study } \\
\text { group also for chemistry every Wednesday. I am planning on contacting student } \\
\text { financial services tomorrow during my free block of time" }\end{array}$ \\
\hline Transferring schools & "I can definitely make the whole year, I want to see my options before I transfer" \\
\hline Orientation & "I already attended my orientation" \\
\hline $\begin{array}{l}\text { Connect with faculty, professor, } \\
\text { academic advisors, or specific other } \\
\text { academic support }\end{array}$ & "I have made appointments to go see my professors next week" \\
\hline Logistics & $\begin{array}{l}\text { Messages related to managerial activities. This category entails general information } \\
\text { about enrollment decisions and admission deadlines }\end{array}$ \\
\hline $\begin{array}{l}\text { Meeting reminders (e.g., with the } \\
\text { counselor) }\end{array}$ & "Do you have any days you can meet at 8:30 or 9?" \\
\hline Plans (e.g., for next semester) & "I do plan on going to college" \\
\hline $\begin{array}{l}\text { Deadlines reminders (e.g., add/drop, } \\
\text { registration, etc.) }\end{array}$ & "Yes we were registered we did that in the spring" \\
\hline Well-being & $\begin{array}{l}\text { This category encompasses messages tailored to assess students' experiences in a } \\
\text { higher education institution }\end{array}$ \\
\hline Reach out and check-in & $\begin{array}{l}\text { "My college needs me to send in some documents but I'm not sure what they are and } \\
\text { I needed help" }\end{array}$ \\
\hline Mental health specific & "That you need to take breaks and practice self-care" \\
\hline Connection/belonging on campus & $\begin{array}{l}\text { "Yeah! I have been connecting with my roommates, everything seems to be going } \\
\text { smoothly" }\end{array}$ \\
\hline Short answers (close-ended questions) & "Yes", "No", "Unsure”, “All”, "Some” \\
\hline Uncategorized & "Thank you!" \\
\hline Stop outs & "STOP” \\
\hline
\end{tabular}




\section{Appendix 2 - Self-efficacy scale}

It is important to highlight that discourse analysis was conducted on a student case basis. This means that we looked at the entire conversation that each student had with program staff. Doing this allowed us to identify not only the type of services that students requested, but also how students solved their questions (self-efficacy skills).

In order to calculate self-efficacy, we assigned relative weights to each component of the discourse. Thus, out of a 100, Purpose was 60, Tone 30, and Length 10. We considered assigning the weights on a presence/absence basis (e.g., it does have purpose vs. does not have purpose, it does have a tone vs. it does not have a tone), but that would have overestimated the number of students who display self-efficacy skills. Instead, and given that each conversation is unique, we created a rubric to distribute scores within each component of the discourse. For example, Purpose was divided into 4 possible scores: 60,40,20, 0 depending on the extent to which the content of the texts (per conversation) was clear. Tone was divided in 4 possible scores: 30, 20,10, and 0 in relation to how students communicated with program staff. Length was divided in 2 possible scores: 10 and 5 based on whether or not the texts were longer than 71 words. The following table summarizes the distribution of points (and the criteria) within each component of the discourse.

\begin{tabular}{|l|l|}
\hline $\begin{array}{l}\text { Component of the } \\
\text { discourse }\end{array}$ & Distribution of scores per component \\
\hline Purpose & $\begin{array}{l}\text { 60 = contains a question and a follow up conversation to show problem-solving skills or an } \\
\text { elaborate response to a question. It is clear that the student has taken action to solve her questions } \\
40=\text { contains a question and a follow up conversation to show some problem-solving skills or } \\
\text { an elaborate response to a question. Student shows intention to solve question, but not action } \\
20=\text { contains a question and some evidence of a follow up conversation. Intention to solve } \\
\text { question is not clear } \\
0=\text { text does not have a purpose (e.g., hello, ok, fine) }\end{array}$ \\
\hline Tone & $\begin{array}{l}30=\text { at least one of the texts is a "thank you", "please" message } \\
20=\text { texts are polite but no "thank you" or "please" message } \\
10=\text { just responds to the question (e.g., yes, no, ok) } \\
0=\text { text is unrelated to any of the questions (e.g., "I am driving now", "who is this?") }\end{array}$ \\
\hline $\begin{array}{l}10=\text { at least one of the texts in the conversation is } 71 \text { words long } \\
5=\text { texts are less than 70 words }\end{array}$ \\
\hline
\end{tabular}

Given that this is an exploratory tool, the cut-off between basic and moderate - advance self-efficacy was set at 41 points. That means that students whose total score is below 41 are considered to have basic self-efficacy skills. Students who score higher than 41 are considered to have moderate - advanced self-efficacy skills. The reason is because measuring soft skills using surveys, literacy tests or SMS is not an easy task. Thus, we consider that students who show some level of engagement with SMS are also cultivating self-efficacy skills. The following box presents the self-efficacy scale for the 2019-2020 cohort. I want to stress that more research needs to be done on this area to validate the tool. It is, however, an initial step to understand whether or not SMS nudges can foster self-efficacy skills.

Self-efficacy scale among students for the $2019-2020$ cohort

$75-100=$ advanced self-efficacy skills

A student who scores within this range demonstrates advanced self-efficacy skills because she or he not only reaches out for help, but also uses the resources and advice for problem-solving

\section{$41-74$ = moderate self-efficacy skills}

A student who scores within this range demonstrates moderate self-efficacy skills because she or he reaches out for help, and attempts to solve the problem (intention to use skills and advice)

\section{$5-40=$ basic self-efficacy skills}

A student who scores within this range demonstrates basic self-efficacy skills because she or he reaches out (sometimes not clear what the student needs), but there is no evidence that the student used or will use the help or resources that program staff suggested 


\section{Appendix 3 - Basic self-efficacy skills (example of a student)}

\begin{tabular}{|c|c|}
\hline message_type & text \\
\hline sent & $\begin{array}{l}\text { Welcome to [program name] Text Messaging Program! Weâ } €^{\mathrm{TM}} 1 \mathrm{l} \text { be sending messages and } \\
\text { financial aid info to support you this final semester of high school and into your first year in college } \\
\text { or other training program. Text this \# to reach your [program name] counselor. We are here to } \\
\text { help! }\end{array}$ \\
\hline sent & If you want to stop getting these messages at any time reply: STOP. \\
\hline sent & if you or your student is planning on attending college next year- here is a scholarship opportunity \\
\hline sent & $\begin{array}{l}\text { [program name] Reminder: Have you logged into your college email yet. Email is the \#1 } \\
\text { communication tool for colleges. Check it every day! }\end{array}$ \\
\hline \multicolumn{2}{|l|}{ sent } \\
\hline sent & $\begin{array}{l}\text { See Requirements for book } \$ \text {. Hint, hint, orientation. Have you registered for or attended } \\
\text { orientation yet? }\end{array}$ \\
\hline sent & $\begin{array}{l}\text { if you or your student plans on going to college in the fall:Â Environmental Awareness } \\
\text { ScholarshipEssay } \\
\text { Deadline: } \\
\text { September }\end{array}$ \\
\hline sent & $\begin{array}{l}\text { [program name] Reminder: Planning to take out federal loans, borrowers need to do loan entrance } \\
\text { counseling \& sign the promissory note. }\end{array}$ \\
\hline sent & Text us with questions. \\
\hline sent & $\begin{array}{l}\text { [program name] Reminder: Have you received your first tuition bill? Call the financial aid office } \\
\text { phone }\end{array}$ \\
\hline sent & $\begin{array}{l}\text { [program name] Reminder: Is your [program name] account up to date with your final school } \\
\text { choice? In BOTH grants This will help your } \$ \text { get to the right place. }\end{array}$ \\
\hline sent & $\begin{array}{l}\text { Go to [program name]and log into your account to update your school and check your [program } \\
\text { name] "to do" list! }\end{array}$ \\
\hline sent & $\begin{array}{l}\text { [program name] Reminder: Have you looked for your FERPA form in your student portal? If you } \\
\text { want anyone to know anything about your bill, grades, etc, you will need to fill out a FERPA form. }\end{array}$ \\
\hline sent & Text if you have questions. \\
\hline sent & $\begin{array}{l}\text { [program name] Reminder: Don't get caught paying for health insurance you don't need. If you } \\
\text { have your own make sure you WAIVE your college's insurance so they don't bill you for theirs! }\end{array}$ \\
\hline sent & $\begin{array}{l}\text { Also make sure your vaccination records are up to date and have a copy with you when you arrive } \\
\text { on campus. }\end{array}$ \\
\hline sent & $\begin{array}{l}\text { Hi, by now you probably know where you'll be living this fall. It's a great time to connect with } \\
\text { your roommates via social media or email! }\end{array}$ \\
\hline sent & $\begin{array}{l}\text { [program name] Reminder: Now's a good time to check your bill again. Grant money doesn"t show } \\
\text { up until after classes start. Call the financial aid office }\end{array}$ \\
\hline
\end{tabular}




\begin{tabular}{|c|c|}
\hline message_type & text \\
\hline sent & $\begin{array}{l}\text { Keep copies of all your financial aid records. Records will help when talking with college financial } \\
\text { aid counselors! }\end{array}$ \\
\hline sent & $\begin{array}{l}\mathrm{Hi} \text {, the deadline for Early Start Move-In registration is tonight at } 5 \mathrm{pm} \text {. Email [email address] to } \\
\text { sign up for this great opportunity and a way to earn money towards your first semester books! }\end{array}$ \\
\hline sent & $\begin{array}{l}\text { [program name] Reminder: Hi, Have you started to think about getting your stuff packed for } \\
\text { school? }\end{array}$ \\
\hline sent & $\begin{array}{l}\text { Most schools provide a packing list to help you figure out what to bring. Check your school website } \\
\text { and orientation materials for the list! }\end{array}$ \\
\hline sent & [program name] Reminder: Hi do you have questions about where to get books? \\
\hline sent & Did you complete your [information] to get book $\$$ ? \\
\hline received & No \\
\hline sent & $\begin{array}{l}\text { Hello, this is [counselor name] if you have questions about the book money I would be happy to } \\
\text { help. }\end{array}$ \\
\hline received & What is the book money? \\
\hline sent & I can email you the information. It looks like we have an old email. What is your current email? \\
\hline received & [email address] \\
\hline received & Thank you! \\
\hline sent & No worries I am sending you an email now :) \\
\hline received & What is SSS Early Start? \\
\hline sent & $\begin{array}{l}\text { I believe you are too late to register for that. I would connect with them and see if you could meet } \\
\text { or talk with an SSS advisor to get details about the program. If you met with anadvisor we might } \\
\text { still be able to give you the money. }\end{array}$ \\
\hline sent & $\begin{array}{l}\text { [program name] Reminder: Tell us how you're feeling about heading off to college. } \ddot{Y}^{\cdots}= \\
\text { completely freaked out and } \succsim \ddot{Y}^{`} \bullet=\text { totally ready }\end{array}$ \\
\hline sent & $\begin{array}{l}\text { are you studying/training in a STEM field?- here is a scholarship for you to apply for- deadline } \\
8 / 16 / 19 \text { : }\end{array}$ \\
\hline received & I'm having trouble finding a number to contact an advisor. \\
\hline sent & here is the page to apply:) \\
\hline sent & contact info: \\
\hline sent & [program name] Reminder: Wishing you a great new beginning! Don't forget we are here to help. \\
\hline sent & $\begin{array}{l}\text { [program name] Reminder: Hi, Wishing you a great new beginning! Your [program name] team } \\
\text { will be texting soon to continue providing support this fall :) }\end{array}$ \\
\hline sent & $\begin{array}{l}\text { Check to make sure that you have your [program name] scholarship "pending" or already processed } \\
\text { on your student account- text with questions. }\end{array}$ \\
\hline
\end{tabular}




\begin{tabular}{|c|c|}
\hline message_type & text \\
\hline sent & $\begin{array}{l}\text { [program name] Reminder: } \mathrm{Hi} \text {, it is getting close to ADD/DROP period for classes. If you are } \\
\text { considering dropping a class make sure to talk to your academic advisor about deadlines as well } \\
\text { as credits, so you don't end up with FEES or failing grades. }\end{array}$ \\
\hline sent & [program name] Reminder: Are you connecting with faculty on campus? Reply yes/no \\
\hline sent & $\begin{array}{l}\text { [program name] Reminder: Hey, Have you found a work-study job, if not, do you know where to } \\
\text { look to find one, they tend to go fast? Reply yes/no }\end{array}$ \\
\hline received & No \\
\hline sent & text if you need help finding info on your school website \\
\hline sent & do you need help knowing next steps to find one? \\
\hline received & Work study job \\
\hline received & Yes please \\
\hline sent & $\begin{array}{l}\text { good morning, i think [college name] sends you an email with what to do next for getting a work } \\
\text { study job. did you get that email? if you haven't gone to your advisor yet, they can help you with } \\
\text { your resume (which you will need to apply for work/study jobs)? }\end{array}$ \\
\hline sent & $\begin{array}{l}\text { [program name] Reminder: Hi, have you found any activities (outside of your classes) that you } \\
\text { want to check out? Reply yes/no }\end{array}$ \\
\hline sent & $\begin{array}{l}\text { [program name] Reminder: Hi, Have you checked the status of your bill in your student portal? } \\
\text { Reply yes/no }\end{array}$ \\
\hline sent & $\begin{array}{l}\text { [program name] Reminder: Living with a roommate can be fun and it can be tough. Ask for help } \\
\text { in working out any challenges that are coming up. Use your Resident Advisor as a resource. }\end{array}$ \\
\hline sent & $\begin{array}{l}\text { [program name] Reminder: Have you talked one-on-one with one of your professors before class, } \\
\text { at break, after class, during office hours? Reply yes/no }\end{array}$ \\
\hline sent & $\begin{array}{l}\text { It can be intimidating. Text if you need help strategizing ways to just say "hello" and tell them your } \\
\text { name- that can be a huge step. }\end{array}$ \\
\hline received & No \\
\hline sent & [program name] Reminder: Hi, Are there any classes that concern you? Reply yes/no \\
\hline sent & $\begin{array}{l}\text { [program name] Reminder: It's a great time to reflect on where you're at after a month of school. } \\
\text { What's going well? What's not? }\end{array}$ \\
\hline sent & Remember that struggles are a part of the process too. Let us know if you need help with anything- \\
\hline sent & $\begin{array}{l}\text { [program name] Reminder: Hi, Have you used the academic support services or tutoring service } \\
\text { on campus? Reply yes/no }\end{array}$ \\
\hline sent & $\begin{array}{l}\text { [program name] Reminder: Hi, How are your grades? Do you know where to check them? Are you } \\
\text { happy with them? Reply yes/no }\end{array}$ \\
\hline
\end{tabular}




\begin{tabular}{|c|c|}
\hline message_type & text \\
\hline sent & $\begin{array}{l}\text { [program name] Reminder: It's not too early- Did you know you can get started renewing the } \\
\text { FAFSA now? Check your school website for their deadline! Go to fafsa.gov to get started. Text if } \\
\text { you need help. }\end{array}$ \\
\hline sent & $\begin{array}{l}\text { Hi, want to help fundraise for scholarships for students like you? Here's the link to the } 5 \mathrm{k} \text { Run } \\
\text { happening at [college name] tomorrow- learn more about how you might be eligible for this } \\
\text { scholarship: }\end{array}$ \\
\hline sent & You might even see your high school outreach counselor:) \\
\hline sent & [program name] Reminder: Hi, Are you feeling stressed from midterms and papers? Reply yes/no \\
\hline sent & $\begin{array}{l}\mathrm{Hi} \text {, this is [counselor name] from [program name]. did you do the [program] to get money towards } \\
\text { required textbooks this semester? if not, it isn't too late, to do a few activities this semester to earn } \\
\$ \text { towards } 2 \text { nd semester books. }\end{array}$ \\
\hline sent & $\begin{array}{l}\text { i will be on campus and can meet between } 9: 30 \text { and } 4: 30 \mathrm{pm} \text { on Wednesday } 10 / 23 \text {. i will be in the } \\
\text { fireplace lounge outside of the tutoring center. text me a time that works for you to meet and i will } \\
\text { sign you up. }\end{array}$ \\
\hline sent & $\begin{array}{l}\text { [program name] Reminder: Hey, this time can be stressful. What have you done today to help take } \\
\text { care of yourself? Eat a good meal? Exercise? }\end{array}$ \\
\hline sent & Not sure where to start? Check activities offered on campus for de-stressing: look for FREE food \\
\hline sent & $\begin{array}{l}\text { [program name] Reminder: Hi, How did mid-terms go? Are you satisfied with how they went? } \\
\text { Reply yes/no }\end{array}$ \\
\hline sent & $\begin{array}{l}\text { [program name] Reminder: Hi, Have you started planning your courses for next semester yet? } \\
\text { Reply yes/no }\end{array}$ \\
\hline sent & Hi, come to the FAFSA workshop on Monday 11/11/19.Â RSVP here to help plan pizza quanities- \\
\hline sent & $\begin{array}{l}\text { Time: } \\
\text { Location: [university address] }\end{array}$ \\
\hline sent & $\begin{array}{l}\text { [program name] Reminder: Are you going home for Thanksgiving? If not, talk to your RA about } \\
\text { fall break housing or see if a friend can host you! }\end{array}$ \\
\hline sent & [program name] Reminder: Break can be a great time to do your FAFSA. Text us if you need help \\
\hline sent & Happy Thanksgiving from your [program name] team. Enjoy! \\
\hline sent & $\begin{array}{l}\text { [program name] invites you to join in on its Facebook Live event with step-by-step instructions on } \\
\text { how to apply for scholarships }\end{array}$ \\
\hline sent & $\begin{array}{l}\text { hi, this is [counselor name] from [program name]. it isn't too late to send in your proof to earn } \$ \\
\text { for } 2 \text { nd semester books (if you haven't already:)). deadline is this friday } 12 / 6 / 19 \text {. text if you have } \\
\text { questions:). }\end{array}$ \\
\hline sent & $\begin{array}{l}\text { [program name] Reminder: Hi, we hope break was relaxing. How are you feeling about finals? } \\
\text { Reply } \partial \ddot{Y}^{\cdots \cdot}=\text { completely freaked out andð } \ddot{Y}^{`} \bullet=\text { totally ready }\end{array}$ \\
\hline sent & [program name] Reminder: Did you have a class you really enjoyed this semester? Reply yes/no \\
\hline sent & $\begin{array}{l}\text { [program name] Reminder: Congratulations on completing your first semester in college! You did } \\
\text { it! Have a relaxing winter break! Text us if you have any questions or need help during this down } \\
\text { time }\end{array}$ \\
\hline
\end{tabular}




\begin{tabular}{|c|c|}
\hline message_type & text \\
\hline sent & $\begin{array}{l}\text { [program name] Reminder: Remember, FAFSA, Scholarship applications have to be filed for each } \\
\text { year you want funding. }\end{array}$ \\
\hline sent & $\begin{array}{l}\text { In addition to re-connecting with family and friends over break, this is a great time to get that done } \\
\text { and apply for scholarships! LMK if you have questions. }\end{array}$ \\
\hline sent & $\begin{array}{l}\text { Hey, it's [counselor name] from [program name] I am the human behind these text messages. I } \\
\text { want to ask you } 5 \text { short questions to learn how we can do a better job helping students in their } 1 \mathrm{st} \\
\text { year of college. If you answer all } 5 \text { of them by Tuesday- January } 7 \text { th at noon, I will enter your } \\
\text { name in a drawing for } \$ \text { towards } 2 \text { nd semester textbooks. Text YES to participate. }\end{array}$ \\
\hline sent & $\begin{array}{l}\text { Hi. Just a reminder to fill out the survey I sent over. If you answer all } 5 \text { of them by Tuesday- } \\
\text { January } 7 \text { th at noon, I will enter your name in a drawing for } \$ 2 \text { towards } 2 \text { nd semester text books. } \\
\text { Text YES to participate. }\end{array}$ \\
\hline sent & $\begin{array}{l}\text { Hey, it's [counselor name] from [program name]. Have you checked your school's financial aid } \\
\text { application deadline for the 2020-2021 school year? Text Yes or No. }\end{array}$ \\
\hline sent & $\begin{array}{l}\text { Hey, it's [counselor name] from [program name]. If you haven't completed the FAFSA application } \\
\text { for the } 2020-2021 \text { school year, visit www.fafsa.gov. Have your } 2018 \text { income information ready. } \\
\text { Text if you need help or have questions. }\end{array}$ \\
\hline sent & $\begin{array}{l}\text { Hey, it's [counselor name] from [program name]. It's time to fill out the } 2020-2021 \text { Application to } \\
\text { receive } \$ \$ \$ \text { for next year- if you haven't already done it } \ddot{Y} \sim \breve{S} \text {. }\end{array}$ \\
\hline sent & WatchFacebook Live event on how to fill out the Application \\
\hline sent & $\begin{array}{l}\text { Hey, it's [counselor name] from [program name]. Before adding or dropping a class this semester } \\
\text { make sure to check your school's academic calendar for the add/drop dates- so you don't get } \\
\text { penalized for missing this deadline- And talk to your Academic Advisor before making a change. }\end{array}$ \\
\hline sent & $\begin{array}{l}\text { Hey, it's [counselor name] from [program name]. Do you feel prepared to take on this semester } \\
\text { and succeed? Reply Yes or No }\end{array}$ \\
\hline sent & $\begin{array}{l}\text { The Student Support Services or Academic Services Office on your campus is also a great resource } \\
\text { for scholarships. }\end{array}$ \\
\hline sent & $\begin{array}{l}\text { Hey, it's [counselor name] from [program name]. Do you feel prepared to take on this semester } \\
\text { and succeed? Reply Yes or No }\end{array}$ \\
\hline sent & $\begin{array}{l}\text { Hey, it's [counselor name] from [program name]. It's a great idea to check your scholarships } \\
\text { account to make sure you are getting your } \$ / \text { year Text if you have questions. }\end{array}$ \\
\hline sent & $\begin{array}{l}\text { Hey, it's [counselor name] from [program name]. MAJOR Confusion? If you have not declared a } \\
\text { major, no worries, your school is probably offering workshops to help. Your advisor and/or } \\
\text { favorite professors could be a great resource. }\end{array}$ \\
\hline sent & $\begin{array}{l}\text { Hey, it's [counselor name] from [program name]. How are your grades? Are you happy with them? } \\
\text { Let } \begin{array}{lllllll}\text { us } & \text { know } & \text { by } & \text { replying } & \text { YES } & \text { or } & \text { NO. }\end{array}\end{array}$ \\
\hline
\end{tabular}




\begin{tabular}{|c|c|}
\hline message_type & text \\
\hline sent & $\begin{array}{l}\text { Hey, [counselor name] from [program name]. It isn't too early to be thinking about summer plans. } \\
\text { Visit the Career Center on your campus to learn about paid summer opportunities or talk to your } \\
\text { professors and older students. Find out what they know }\end{array}$ \\
\hline sent & $\begin{array}{l}\text { Hey, it's [counselor name] from [program name]. Spring break is right around the corner, yay! } \\
\text { Your school may be offering spring break programs. Check them out. Or picking up some extra } \\
\text { work hours for } \$ \text { is a great option, too. }\end{array}$ \\
\hline sent & $\begin{array}{l}\text { Hey it's [counselor name] from [program name], I wanted to check in and see how you are doing. } \\
\text { You have a lot of information coming at you and it may feel like it's changing every day. It's ok to } \\
\text { be anxious and confused. Let me know if you need help problem solving. We are here for you. }\end{array}$ \\
\hline sent & $\begin{array}{l}\text { Hey, it's [counselor name] from [program name]. Sending this message in case you or anyone you } \\
\text { know has federal student loans. Federal student loan payments suspended and interest waived } \\
\text { during corona-virus }\end{array}$ \\
\hline sent & $\begin{array}{l}\text { Good morning first_namexâ€く, it's [counselor name] from [program name] again. Are you } \\
\text { struggling with internet access or do you know someone who is? Here is a map to show you places } \\
\text { you can access WiFi around the state. As always, text if you have questions or need help finding } \\
\text { resources. I am in fact a human and not a robot and am here to help:) }\end{array}$ \\
\hline sent & hey i meant to say hello to you in the first message. sorry about that:) \\
\hline sent & $\begin{array}{l}\text { Hey, it's [counselor name] from [program name]. Need a summer class to help you stay on track? } \\
\text { Let us know, [program name] can help with summer funding } \$ \$ \$ \text {. }\end{array}$ \\
\hline sent & $\begin{array}{l}\text { Hey, it's [counselor name] from [program name] again. With all that's going on, we just want you } \\
\text { to know that we are here to be a problem solving partner. TEXT back if you need help finding } \\
\text { resources around: food, housing, technology, education related needs, etc..... }\end{array}$ \\
\hline sent & $\begin{array}{l}\text { He, it's [counselor name] from [program name]. Do you need help with emergency funding related } \\
\text { to COVID 19? Housing, Technology, Food, Healthcare, etc. }\end{array}$ \\
\hline sent & $\begin{array}{l}\text { Here are } 3 \text { great } \\
\text { 1. contact your school's financial aid office and ask about emergency funding- each school is } \\
\text { handling } \\
\text { 2. text me and ask about [program name] emergency micro-grant }\end{array}$ \\
\hline sent & 1. An online tool to appeal your school's financial aid award offer: \\
\hline sent & $\begin{array}{l}\text { Hey, it's [counselor name] from [program name] We know a lot happened this spring that couldn't } \\
\text { be planned for. Have your financial circumstances changed since renewing your FAFSA? Text } \\
\text { back. We are here to help ðY̌ } \ddot{S}^{\sim} \text {. Here are some resources for you if needed: }\end{array}$ \\
\hline sent & $\begin{array}{l}\text { Hey, it's [counselor name] from [program name]. Moving to online may have been a big transition } \\
\text { for you. Was your academic performance affected by all that happened around COVID? Text back } \\
\text { "yes" or "no" }\end{array}$ \\
\hline sent & $\begin{array}{l}\text { Hey, it's [counselor name] from [program name]. We wanted to check and see if your plans for } \\
\text { next year have changed. Are you thinking of transferring? }\end{array}$ \\
\hline
\end{tabular}




\begin{tabular}{|l|l|}
\hline message_type & text \\
\hline sent & $\begin{array}{l}\text { Hi, this is [counselor name] from [program name]. I want to ask you a few short questions to learn } \\
\text { how to do a better job of helping first year students. If you answer all of them (within 24 hours) I } \\
\text { will enter your name into a drawing for \$ toward textbooks. Text YES to participate. }\end{array}$ \\
\hline sent & $\begin{array}{l}\text { Hi. There's still time to finish the survey and be entered into the drawing. Text back YES to } \\
\text { participate. }\end{array}$ \\
\hline
\end{tabular}

Real names were changed. Also, phone numbers and email addresses were altered to protect identities of student and program staff

\section{Appendix 4 - Advanced self-efficacy skills (example of a student)}

\begin{tabular}{|c|c|}
\hline message_type & text \\
\hline sent & $\begin{array}{l}\text { Hi, Welcome to [program name] Text Messaging Program! We'll be sending messages and } \\
\text { financial aid info to support you this final semester of high school and into your first year in } \\
\text { college or other training program. Text this \# to reach your counselor. We are here to help! }\end{array}$ \\
\hline sent & If you want to stop getting these messages at any time reply: STOP. \\
\hline sent & Do you plan on going to college? \\
\hline sent & 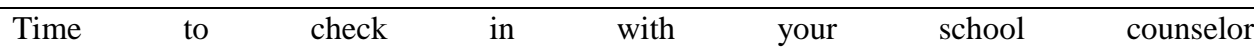 \\
\hline received & Yes \\
\hline sent & $\begin{array}{l}\text { Have you made your final choice? Most colleges require students to submit a deposit and } \\
\text { commit to attend by May } 1 \text { st. }\end{array}$ \\
\hline sent & 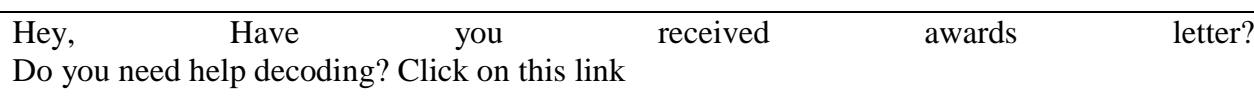 \\
\hline sent & $\begin{array}{l}\text { How is decoding your award letters going? Need help? Text for help or Need to write an appeal } \\
\text { letter? If needed-let us know how we can help }\end{array}$ \\
\hline sent & $\begin{array}{l}\text { Hello, This is [counselor name]. Did you get my email about the [college name] transition day } \\
\text { on Tuesday the 30th? We also have an appointment Monday at 12:30 }\end{array}$ \\
\hline sent & Have questions about loans? There's a lot to understand and we have a guide to help you \\
\hline sent & $\begin{array}{l}\text { College Decision Day is tomorrow! Time to make your choice and contact your school. Check } \\
\text { to see if there is a deposit due. Text with questions }\end{array}$ \\
\hline sent & Hello, checking in on your final college choice. Text us your decision. \\
\hline received & [college name] \\
\hline sent & yay! that's great! congratulations! \\
\hline sent & $\begin{array}{l}\text { Are you taking any AP Exams? If you are, call admissions at your college of choice and ask } \\
\text { where to send them. }\end{array}$ \\
\hline sent & Here is another scholarship opportunity: \\
\hline
\end{tabular}




\begin{tabular}{|c|c|}
\hline sent & $\begin{array}{l}\text { Time to crunch the numbers! What is the gap between your total college costs and the financial } \\
\text { aid you receive? }\end{array}$ \\
\hline sent & If you have to borrow money- here is a link to help with loans: \\
\hline sent & Not all education loans are created equal it's important to educate yourself. Ask for help! \\
\hline sent & $\begin{array}{l}\text { for those of you with a plan to go to college next year- here is a scholarship opportunity for you } \\
\text { to check out: }\end{array}$ \\
\hline sent & $\begin{array}{l}\text { Hey now is a good time to check in with your financial aid office, and make sure everything is } \\
\text { in order. }\end{array}$ \\
\hline sent & You may need to talk about a payment plan or make other arrangements. \\
\hline sent & Have you met with your Counselor recently? \\
\hline sent & $\begin{array}{l}\text { Graduation is right around the corner! We will be texting throughout the summer and next year } \\
\text { to help you stay on track with all things college and career planning. }\end{array}$ \\
\hline sent & Text with questions and ask for help \\
\hline sent & $\begin{array}{l}\text { if you or your student is planning on attending college next year- here is a scholarship } \\
\text { opportunity: }\end{array}$ \\
\hline sent & $\begin{array}{l}\text { [program name] Reminder: Hi, Have you logged into your college email yet. Email is the \#1 } \\
\text { communication tool for colleges. Check it every day! }\end{array}$ \\
\hline sent & $\begin{array}{l}\text { See Requirements for book \$. Hint, hint, orientation. Have you registered for or attended } \\
\text { orientation yet? }\end{array}$ \\
\hline sent & $\begin{array}{l}\text { if you or your student plans on going to college in the fall: Environmental Awareness } \\
\text { Scholarship } \\
\text { Deadline: } \\
\text { September }\end{array}$ \\
\hline sent & $\begin{array}{l}\text { [program name] Reminder: Planning to take out federal loans, borrowers need to do loan } \\
\text { entrance counseling \& sign the promissory note. }\end{array}$ \\
\hline sent & Text us with questions. \\
\hline sent & $\begin{array}{l}\text { [program name] Reminder: Have you received your first tuition bill? Call the financial aid } \\
\text { office phone }\end{array}$ \\
\hline sent & $\begin{array}{l}\text { [program name] Reminder: Is your account up to date with your final school choice? In BOTH } \\
\text { grants. This will help your } \$ \text { get to the right place. }\end{array}$ \\
\hline sent & $\begin{array}{l}\text { Go to [program name] and log into your account to update your school and check your "to do" } \\
\text { list! }\end{array}$ \\
\hline sent & $\begin{array}{l}\text { [program name] Reminder: Have you looked for your FERPA form in your student portal? If } \\
\text { you want anyone to know anything about your bill, grades, etc, you will need to fill out a } \\
\text { FERPA form. }\end{array}$ \\
\hline sent & Text if you have questions. \\
\hline sent & $\begin{array}{l}\text { [program name] Reminder: Don't get caught paying for health insurance you don't need. If you } \\
\text { have your own make sure you WAIVE your college's insurance so they don't bill you for theirs! }\end{array}$ \\
\hline sent & $\begin{array}{l}\text { Also make sure your vaccination records are up to date and have a copy with you when you } \\
\text { arrive on campus. }\end{array}$ \\
\hline
\end{tabular}




\begin{tabular}{|c|c|}
\hline sent & $\begin{array}{l}\text { Hi, by now you probably know where you'll be living this fall. It's a great time to connect with } \\
\text { your roommates via social media or email! }\end{array}$ \\
\hline sent & $\begin{array}{l}\text { [program name] Reminder: Now's a good time to check your bill again. Grant money doesn"t } \\
\text { show up until after classes start. Call the financial aid office phone }\end{array}$ \\
\hline sent & $\begin{array}{l}\text { Keep copies of all your financial aid records. Records will help when talking with college } \\
\text { financial aid counselors! }\end{array}$ \\
\hline sent & $\begin{array}{l}\mathrm{Hi}<\text {, the deadline for Early Start Move-In registration is tonight at } 5 \mathrm{pm} \text {. Email to sign up for } \\
\text { this great opportunity and a way to earn money towards your first semester books! }\end{array}$ \\
\hline sent & $\begin{array}{l}\text { [program name] Reminder: Hi, Have you started to think about getting your stuff packed for } \\
\text { school? }\end{array}$ \\
\hline sent & $\begin{array}{l}\text { Most schools provide a packing list to help you figure out what to bring. Check your school } \\
\text { website and orientation materials for the list! }\end{array}$ \\
\hline sent & [program name] Reminder: Hi do you have questions about where to get books? \\
\hline sent & Did you complete your application to get book $\$$ ? \\
\hline received & What is the application? \\
\hline sent & $\begin{array}{l}\text { Hellothis is [counselor name]. It is the program we talked about to get money toward you } \\
\text { textbooks. I gave you a print out at school. I can send you another email. What is your current } \\
\text { email? }\end{array}$ \\
\hline sent & Hey, [counselor name] again. I just sent you an email. Take a look and let me know. \\
\hline sent & $\begin{array}{l}\text { [program name]Reminder: Tell us how you're feeling about heading off to college. } ð \ddot{Y}^{* *}= \\
\text { completely freaked out and } ð \ddot{Y}^{`} \bullet=\text { totally ready }\end{array}$ \\
\hline sent & $\begin{array}{l}\text { are you studying/training in a STEM field?- here is a scholarship for you to apply for- deadline } \\
8 / 16 / 19 \text { : }\end{array}$ \\
\hline received & $\begin{array}{l}\text { I wasn't able to join any early sss starts. Is there anything else I could do to get money towards } \\
\text { book for this fall or is it too late? }\end{array}$ \\
\hline sent & Hello, its [counselor name], is there any chance you could still get into the orientation \\
\hline sent & $\begin{array}{l}\text { I don't think you will be able to get into the orientation. You can schedule an appointment with } \\
\text { an Advisor and that will work for textbooks. Here is the link to do that: }\end{array}$ \\
\hline received & I've sent an email yesterday they just haven't responded yet \\
\hline sent & Morning, [counselor name] here! I would give the office a call today \\
\hline received & I tried called but looks like the trio head manger is out of town till the 19th of August \\
\hline sent & $\begin{array}{l}\text { hey can. this is [counselor name]. I work with [counselor name]. when are you wanting to buy } \\
\text { your books. if you can forward me the email showing that you are trying to schedule with }\end{array}$ \\
\hline sent & $\begin{array}{l}\text { them. I can set you up with an account this afternoon. that will likely be active on Friday. and } \\
\text { then please send confirmation that you met with trio }\end{array}$ \\
\hline sent & and are a trip student:) \\
\hline received & And hopefully as soon as possible \\
\hline
\end{tabular}




\begin{tabular}{|c|c|}
\hline sent & $\begin{array}{l}\text { hi, this is [counselor name] before setting up a bookstore account for you- we need proof that } \\
\text { you applied to the program or are set up with an appointment with an advisor in the near future- } \\
\text { can you forward that to me either with a picture or email }\end{array}$ \\
\hline received & $\begin{array}{l}\text { I mailed the application papers already. Is there another way for me to show you I applied for } \\
\text { the program? }\end{array}$ \\
\hline sent & $\begin{array}{l}\text { did you get an email from anyone in the program confirming that they got your paperwork or } \\
\text { emails of you working to set up a meeting? }\end{array}$ \\
\hline sent & $\begin{array}{l}\text { [program name] Reminder: Wishing you a great new beginning! Don't forget we are here to } \\
\text { help. }\end{array}$ \\
\hline received & $\begin{array}{l}\text { I don't know if it's too late or not yet but I just forwarded the email scheduling an appointment } \\
\text { with a trio advisor. I'm sorry about how last minute it is. I think the director just got back from } \\
\text { vacation and just responded to my emails I've seen weeks prior. }\end{array}$ \\
\hline sent & $\begin{array}{l}\text { good morning, i see your email and you are set on that front:). next step: send us a picture of } \\
\text { your bill with a } \$ 0 \text { balance or let us know if you have questions about your bill. we want to } \\
\text { make sure you have your grant }\end{array}$ \\
\hline sent & send your ID number and I can set you up with an account at the bookstore:) \\
\hline received & Did u get the picture? \\
\hline received & $\begin{array}{l}\text { And my mom already paid for the books last night because she didn't want me getting them } \\
\text { late. Is there a way to get money for the books still? Should I cancel the order and then go off } \\
\text { the account you guys will be making me? }\end{array}$ \\
\hline sent & hi. can you email pic to [email address] \\
\hline sent & did she order them from bookstore or online? \\
\hline received & On the bookstore \\
\hline sent & $\begin{array}{l}\text { when you go and pick them up you can ask to return some and repurchase for the } \$ \text { account? } \\
\text { would that work for you? }\end{array}$ \\
\hline sent & nice work. just got the picture of your bill- did you make sure you see your award? \\
\hline received & Yeah that sounds good thank you!! \\
\hline sent & what is your student id \# and i can set up an account for you today \\
\hline received & [phone number] \\
\hline received & I don't see anything about award \\
\hline sent & $\begin{array}{l}\text { just sent the email. i recommend checking with financial aid to make sure that } \$ \text { will not affect } \\
\text { your aid. text if you have questions:) }\end{array}$ \\
\hline received & Alright will do. Thank you with everything again!! \\
\hline sent & $\begin{array}{l}\text { i see it in your account- it might just be pending because they don't send the money until after } \\
\text { classes have started:)- thanks for looking! }\end{array}$ \\
\hline received & Did u send the email to [email address]? \\
\hline sent & sorry. no. the email was sent to the bookstore to setup your account not to you:) \\
\hline received & $\begin{array}{l}\text { Ahh gotcha so when I go into pick up my books I return \$ worth of books then use that account } \\
\text { to cover it? }\end{array}$ \\
\hline
\end{tabular}




\begin{tabular}{|c|c|}
\hline sent & $\begin{array}{l}\text { exactly:) and don't take the covers off of any of them until you confirm with your professors } \\
\text { on the first day of class that they are actually using them }\end{array}$ \\
\hline sent & $\begin{array}{l}\text { [program name] Reminder: Hi, Wishing you a great new beginning! Your [program name] } \\
\text { team will be texting soon to continue providing support this fall :) }\end{array}$ \\
\hline sent & $\begin{array}{l}\text { Check to make sure that you have your Grant "pending" or already processed on your student } \\
\text { account- text with questions. }\end{array}$ \\
\hline sent & $\begin{array}{l}\text { [program name] Reminder: Hi, it is getting close to ADD/DROP period for classes. If you are } \\
\text { considering dropping a class make sure to talk to your academic advisor about deadlines as } \\
\text { well as credits, so you don't end up with FEES or failing grades. }\end{array}$ \\
\hline sent & [program name] Reminder: Are you connecting with faculty on campus? Reply yes/no \\
\hline received & Yes \\
\hline sent & Happy to hear! \\
\hline sent & $\begin{array}{l}\text { [program name] Reminder: Hey, Have you found a work-study job, if not, do you know where } \\
\text { to look to find one, they tend to go fast? Reply yes/no }\end{array}$ \\
\hline sent & $\begin{array}{l}\text { [program name] Reminder: Hi, have you found any activities (outside of your classes) that you } \\
\text { want to check out? Reply yes/no }\end{array}$ \\
\hline sent & $\begin{array}{l}\text { [program name] Reminder: Have you checked the status of your bill in your student portal? } \\
\text { Reply yes/no }\end{array}$ \\
\hline sent & $\begin{array}{l}\text { [program name] Reminder: Living with a roommate can be fun and it can be tough. Ask for } \\
\text { help in working out any challenges that are coming up. Use your Resident Advisor as a } \\
\text { resource. }\end{array}$ \\
\hline sent & $\begin{array}{l}\text { [program name] Reminder: Have you talked one-on-one with one of your professors before } \\
\text { class, at break, after class, during office hours? Reply yes/no }\end{array}$ \\
\hline sent & [program name] Reminder: Hi, Are there any classes that concern you? Reply yes/no \\
\hline sent & $\begin{array}{l}\text { [program name] Reminder: It's a great time to reflect on where you're at after a month of school. } \\
\text { What's going well? What's not? }\end{array}$ \\
\hline sent & $\begin{array}{l}\text { Remember that struggles are a part of the process too. Let us know if you need help with } \\
\text { anything }\end{array}$ \\
\hline sent & $\begin{array}{l}\text { [program name] Reminder: Hi, Have you used the academic support services or tutoring service } \\
\text { on campus? Reply yes/no }\end{array}$ \\
\hline sent & $\begin{array}{l}\text { [program name] Reminder: Hi, How are your grades? Do you know where to check them? Are } \\
\text { you happy with them? Reply yes/no }\end{array}$ \\
\hline sent & $\begin{array}{l}\text { [program name] Reminder: It's not too early- Did you know you can get started renewing the } \\
\text { FAFSA now? Check your school website for their deadline! Go to fafsa.gov to get started. Text } \\
\text { if you need help. }\end{array}$ \\
\hline sent & $\begin{array}{l}\text { Hi, want to help fundraise for scholarships for students like you? Here's the link to the } 5 \mathrm{k} \text { Run } \\
\text { happening at [college name] tomorrow- learn more about how you might be eligible for this } \\
\text { scholarship: }\end{array}$ \\
\hline sent & You might even see your high school outreach counselor:) \\
\hline sent & $\begin{array}{l}\text { [program name] Reminder: Hi, Are you feeling stressed from midterms and papers? Reply } \\
\text { yes/no }\end{array}$ \\
\hline
\end{tabular}




\begin{tabular}{|c|c|}
\hline sent & $\begin{array}{l}\text { Hi this is [counselor name] from [program name]. did you do the application to get } \$ \text { towards } \\
\text { required textbooks this semester? if not, it isn't too late, to do a few activities this semester to } \\
\text { earn } \$ \text { towards } 2 \text { nd semester books. }\end{array}$ \\
\hline sent & $\begin{array}{l}\text { i will be on campus and can meet between } 9: 30 \text { and } 4: 30 \mathrm{pm} \text { on Wednesday } 10 / 23 \text {. i will be in } \\
\text { the fireplace lounge outside of the tutoring center. text me a time that works for you to meet } \\
\text { and i will sign you up. we can also look at your fafsa }\end{array}$ \\
\hline received & $\begin{array}{l}\text { Hi [counselor name], I haven't done the [program name] yet and I would love to. How long do } \\
\mathrm{u} \text { think the meeting will take? My schedule next Wednesday is kinda tight at the moment }\end{array}$ \\
\hline sent & $\begin{array}{l}\text { we can meet for as quickly as you are available if you want- } \mathrm{i} \text { am scheduling students for about } \\
30 \text { mins right now. is there a day that works better for you and i could set up another day, too? }\end{array}$ \\
\hline received & $\begin{array}{l}\text { Tuesday's and Thursday's typically work better because I only have } 1 \text { class at } 1: 15-2: 30 \text {. If } \\
\text { those days don't work for you then I can stop by Wednesday after my first class which ends at } \\
11: 40 \text { for about } 30 \mathrm{mins}\end{array}$ \\
\hline sent & $\begin{array}{l}\text { let's try for that and if we need more time (I have another student coming at noon) and if we } \\
\text { need to schedule for another- } i \text { am sure we can find a tue/thur that works for both of us:). how } \\
\text { does that sound? }\end{array}$ \\
\hline sent & and do you know where this spot is on campus? \\
\hline received & $\begin{array}{l}\text { Sounds perfect, I'll head on over after my morning class. I think I know where it is but not } \\
\text { certain. }\end{array}$ \\
\hline sent & $\begin{array}{l}\text { do you know where the [place]? you go up to the } 2 \text { nd floor from there and you turn to the right } \\
\text { at the top of those stairs and you'll see the lounge and tutoring center. }\end{array}$ \\
\hline sent & $\begin{array}{l}\text { [program name] Reminder: Hey, this time can be stressful. What have you done today to help } \\
\text { take care of yourself? Eat a good meal? Exercise? }\end{array}$ \\
\hline sent & $\begin{array}{l}\text { Not sure where to start? Check activities offered on campus for de-stressing: look for FREE } \\
\text { food }\end{array}$ \\
\hline received & $\begin{array}{l}\text { Liked do you know where the [place]? you go up to the } 2 \text { nd floor from there and you turn to } \\
\text { the right at the top of those stairs and you'll see the lounge and tutoring center.â€ }\end{array}$ \\
\hline received & $\begin{array}{l}\text { Loved â€œdo you know where [place]? you go up to the } 2 \text { nd floor from there and you turn to } \\
\text { the right at the top of those stairs and you'll see the lounge and tutoring center.â€ }\end{array}$ \\
\hline sent & $\begin{array}{l}\text { [program name] Reminder: Hi, How did mid-terms go? Are you satisfied with how they went? } \\
\text { Reply yes/no }\end{array}$ \\
\hline sent & $\begin{array}{l}\text { good morning, looking forward to meeting you today! i am sitting in the back corner of the } \\
\text { fireplace lounge by the back windows on the far side from the fireplace:) }\end{array}$ \\
\hline sent & hi, are you still able to meet today? \\
\hline sent & $\begin{array}{l}\text { [program name] Reminder: Hi, Have you started planning your courses for next semester yet? } \\
\text { Reply yes/no }\end{array}$ \\
\hline sent & $\begin{array}{l}\text { Hi, come to the FAFSA workshop on Monday 11/11/19. RSVP here to help plan pizza } \\
\text { quanities }\end{array}$ \\
\hline sent & $\begin{array}{l}\text { Time: } \\
\text { Location: [university address] }\end{array}$ \\
\hline sent & $\begin{array}{l}\text { [program name] Reminder: Are you going home for Thanksgiving? If not, talk to your RA } \\
\text { about fall break housing or see if a friend can host you! }\end{array}$ \\
\hline
\end{tabular}




\begin{tabular}{|c|c|}
\hline sent & $\begin{array}{l}\text { [program name] Reminder: Break can be a great time to do your FAFSA Text us if you need } \\
\text { help }\end{array}$ \\
\hline sent & Happy Thanksgiving from your [program name] team. Enjoy! \\
\hline sent & $\begin{array}{l}\text { [program name] invites you to join in on its Facebook Live event with step-by-step instructions } \\
\text { on how to apply for scholarships }\end{array}$ \\
\hline received & Thank you! \\
\hline sent & sure thing:). did you want to follow-up about the book money? and book $\$$ for 2 nd semester? \\
\hline received & Yes, that would be great! \\
\hline sent & were you able to do the task on the application I gave you? \\
\hline sent & $\begin{array}{l}\text { hi, this is [counselor name] from [program name]. it isn't too late to send in your proof to earn } \\
\$ \text { for 2nd semester books (if you haven't already:)). deadline is this friday } 12 / 6 / 19 \text {. text if you } \\
\text { have questions:). }\end{array}$ \\
\hline received & Where can I find the info on the application to earn $\$$ for 2 nd semester? \\
\hline sent & $\begin{array}{l}\text { 1. } \\
\text { 1. meet }\end{array}$ \\
\hline sent & please text with questions or if you need help:) \\
\hline received & If I've gone to my academic advisor, does that count? \\
\hline sent & $\begin{array}{l}\text { did you meet with them beyond registering for classes? our goal is for you to find supports on } \\
\text { campus and by doing the activities I listed you can apply for } \$ \$ \$ \text { through their program.... }\end{array}$ \\
\hline sent & $\begin{array}{l}\text { if you can tell me a little more about your meetings with your academic advisor we can see if } \\
\text { it works or if you went to tutoring or other supports. here is the link: }\end{array}$ \\
\hline received & $\begin{array}{l}\text { The meeting was focused on what classes to take based on my concentration in the [college } \\
\text { name] and my potential minor. I don't think it'll meet the requirement but I'll schedule other } \\
\text { appointments this week to help me with finals week coming up }\end{array}$ \\
\hline sent & $\begin{array}{l}\text { if you're eligible for the application and think that is a helpful resource- fill out the application } \\
\text { and send me proof that you connected with an advisor- have you gone to tutoring? or study } \\
\text { groups? office hours? introduced yourself to a professor? }\end{array}$ \\
\hline sent & $\begin{array}{l}\text { we also want you to look at your bill for } 2 \text { nd semester and text us if you have questions- we } \\
\text { know you have a ton going on and want this to be helpful NOT another thing to add to your to- } \\
\text { do list }\end{array}$ \\
\hline received & $\begin{array}{l}\text { If Iâ€ } €^{\mathrm{TM}_{\mathrm{v}}} \text { met with my Advisor towards the beginning of the semester, does that apply or do I } \\
\text { need to meet with him again? }\end{array}$ \\
\hline sent & yes! and one more check in and your bill:) \\
\hline sent & $\begin{array}{l}\text { even an email to your trio advisor asking about how to be eligible to apply for their } \\
\text { supplemental grant would do it:) }\end{array}$ \\
\hline received & Ok thank you so much!! \\
\hline sent & $\begin{array}{l}\text { [program name] Reminder: Hi, we hope break was relaxing. How are you feeling about finals? } \\
\text { Reply } \ddot{Y}^{\cdots \cdot}=\text { completely freaked out andð } \ddot{Y}^{`} \bullet=\text { totally ready }\end{array}$ \\
\hline received & 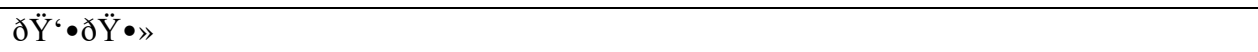 \\
\hline
\end{tabular}




\begin{tabular}{|c|c|}
\hline received & Who do I forward the emails to for proof? \\
\hline received & And it's says I have $\$$ to pay which is concerning \\
\hline sent & [email address] \\
\hline sent & your bill says you owe $\$ ?$ \\
\hline received & $\begin{array}{l}\text { Yes under charges since 11/14/2019, it shows } \$ \text {. Doesn't show any pending financial aid or } \\
\text { additional resources bc I haven't filled any of that out yet. }\end{array}$ \\
\hline sent & $\begin{array}{l}\text { do you have time tomorrow to chat by phone with me? or to call student financial services and } \\
\text { ask them to walk you through your bill? what would work better for you? }\end{array}$ \\
\hline received & $\begin{array}{l}\text { Tomorrow might not be the best time, I have a lot of stuff due Thursday that I need to complete. } \\
\text { Thursday evening will be a better time for me if that works for you? }\end{array}$ \\
\hline sent & $\begin{array}{l}\text { i'm available until about 4:30pm on Thursday and all day Friday- I know now is a super busy } \\
\text { time for you- so we'll work on finding a time if that doesn't work for you }\end{array}$ \\
\hline received & Friday sounds perfect. I can call after my last class which will end around 2:00. \\
\hline sent & sounds great- you can reach me on my cell [phone number] have a good night! \\
\hline sent & [program name] Reminder: Did you have a class you really enjoyed this semester? Reply yes/no \\
\hline received & Where do I go to give my application? \\
\hline sent & $\begin{array}{l}\text { do you remember where we met in the fireplace lounge? They are down the hall from the } \\
\text { tutoring center. Turn right at the deadend. Does it say on the application that you can email it } \\
\text { to them if you have a scanner? or does it need to be turned in as a hardcopy? }\end{array}$ \\
\hline received & I'm not sure I'm in class rn so I'll check afterwards but thank you so much!!! \\
\hline sent & $\begin{array}{l}\text { no worries. are we still talking today at } 2 \mathrm{pm} \text { about your bill? We can talk then about turning in } \\
\text { your application }\end{array}$ \\
\hline received & Yes I am and that'd be perfect!! \\
\hline sent & cool. i will give you a call now. it will be from a [phone number]- beware:) \\
\hline received & $\begin{array}{l}\text { Actually, I didn't realize we had class today but I'm in class right now. Can we talk around like } \\
\text { 3ish? I'm sorry for the inconvenience }\end{array}$ \\
\hline sent & [phone number] \\
\hline received & $\begin{array}{l}\text { What learned from Student } \text { Financial } \\
\text { The bill at the moment is a work in progress. Everything is still being generated and the final } \\
\text { bill will come out on the 13th of December. I was concerned about the coat because I thought } \\
\text { the bill per semester was going to be smaller than it actually is based on the information I } \\
\text { received about my bill prior to coming to [university name]. However, after having gone over } \\
\text { my bill with student financial services, I learned what actually went into bill, such as classes, } \\
\text { tuition, room/ board, and meal plan. In addition I learned that I need to get more aid and apply } \\
\text { for more scholarships for future semesters so it is not as expensive. }\end{array}$ \\
\hline sent & $\begin{array}{l}\text { that's great! and hard info to get. i'm sorry your bill is larger than expected! next step talk to } \\
\text { them about their scholarship and other scholarships they know about that you can apply for- } \\
\text { they are a great resource for all kinds of scholarships:) }\end{array}$ \\
\hline received & Of course, will do. Thank you again!!! \\
\hline
\end{tabular}




\begin{tabular}{|c|c|}
\hline sent & $\begin{array}{l}\text { [program name] Reminder: Congratulations on completing your first semester in college! You } \\
\text { did it! Have a relaxing winter break! Text us if you have any questions or need help during this } \\
\text { down time }\end{array}$ \\
\hline sent & $\begin{array}{l}\text { [program name] Reminder: Remember, FAFSA, Scholarship applications have to be filed for } \\
\text { each year you want funding. }\end{array}$ \\
\hline sent & $\begin{array}{l}\text { In addition to re-connecting with family and friends over break, this is a great time to get that } \\
\text { done and apply for scholarships! LMK if you have questions. }\end{array}$ \\
\hline sent & $\begin{array}{l}\text { Hey, it's [counselor name] from [program name]. Yay! Your bookstore account is now active. } \\
\text { You are eligible to buy up to \$ of your required textbooks for this semester. Text if you plan to } \\
\text { purchase online and I can send instructions. I also recommend you call financial aid before } \\
\text { spending the } \$ \text { and ask "will \$ of a book scholarship affect my financial aid award?". Text if } \\
\text { you have questions:) }\end{array}$ \\
\hline sent & $\begin{array}{l}\text { Hey, it's [counselor name] from [program name]. I am the human behind these text messages. } \\
\text { I want to ask you } 5 \text { short questions to learn how we can do a better job helping students in their } \\
1 \text { st year of college. If you answer all } 5 \text { of them by Tuesday- January } 7 \text { th at noon, I will enter } \\
\text { your name in a drawing for } \$ \text { towards } 2 \text { nd semester text books. Text YES to participate. }\end{array}$ \\
\hline sent & $\begin{array}{l}\text { Q1. How many of the books required for your FALL classes did you buy/rent? Text back A } \\
\text { (all), S (some), or } \mathrm{N} \text { (none). }\end{array}$ \\
\hline received & Yes \\
\hline received & $\mathrm{A}$ \\
\hline sent & $\begin{array}{l}\text { Q2. Have you ever spoken with someone in your college's financial aid office (in person or on } \\
\text { the phone)? Text back Y (yes) or N (no). }\end{array}$ \\
\hline received & $\mathrm{Y}$ \\
\hline sent & $\begin{array}{l}\text { Q3. Did you ever go to the Academic Support Services or Student Support Services office on } \\
\text { your campus? (You may have gone for tutoring, FAFSA renewal help, to drop in for food, etc.) } \\
\text { Text Y (yes), N (no), or U (unsure). }\end{array}$ \\
\hline received & $\mathrm{Y}$ \\
\hline sent & $\begin{array}{l}\text { Q4. Is there a college faculty or staff member you feel comfortable asking for help or advice? } \\
\text { If yes, text back who (for example: Academic advisor, student support services staff member, } \\
\text { residence advisor, counselor, etc.) If not, text } \mathrm{N} \text { (no). }\end{array}$ \\
\hline sent & $\begin{array}{l}\text { Q5. How connected did you feel to campus during the fall semester? Text back a number from } \\
1 \text { (not at all connected) to } 5 \text { (very connected). }\end{array}$ \\
\hline received & Yes, academic advisor/trio advisor \\
\hline received & 4 \\
\hline sent & $\begin{array}{l}\text { Thank you for answering my questions! Your name is in the drawing for } \$ \text { book money, and I } \\
\text { will contact the winner by Jan } 7 \text { th. Remember, [program name] is here to help if you have any } \\
\text { other questions }\end{array}$ \\
\hline sent & $\begin{array}{l}\text { congratulations! you won the drawing for } \$ \text { towards your bookstore account:). i recommend } \\
\text { calling financial aid first before you spend the } \$ \text { and make sure that more book scholarship } \$ \\
\text { won't affect your financial aid. please let me know what you find out and i can set up the account } \\
\text { for you }\end{array}$ \\
\hline sent & i'll wait to hear from you to make sure it won't mess anything up \\
\hline
\end{tabular}




\begin{tabular}{|c|c|}
\hline sent & $\begin{array}{l}\text { Hey, it's [counselor name] from [program name]. Have you checked your school's financial aid } \\
\text { application deadline for the 2020-2021 school year? Text Yes or No. }\end{array}$ \\
\hline received & $\begin{array}{l}\text { Hi [counselor name], sorry for the late response but I just got my wisdom teeth out a few days } \\
\text { ago so I've been resting a lot. I'll check with them about all this as soon as I can!! }\end{array}$ \\
\hline sent & $\begin{array}{l}\text { no worries-- we're here when you need it! If you're staying at [college name], their deadline is } \\
2 / 1 / 2020 \text {. }\end{array}$ \\
\hline sent & $\begin{array}{l}\text { hi, it's [counselor name] sorry about the wisdom teeth! i'll wait to hear from you about book } \\
\text { money:) }\end{array}$ \\
\hline sent & $\begin{array}{l}\text { Hi, i hope you are feeling better! have you had a chance to check with SFS to see if } \$ \text { book } \\
\text { scholarship will affect your aid? i can put that money in your bookstore account as soon as you } \\
\text { give me the go ahead:) }\end{array}$ \\
\hline received & $\begin{array}{l}\text { I've emailed them and they haven't gotten back to me yet. I've tried calling but it's been very } \\
\text { busy for them is what they've told me so hopefully they get back to me quickly. Sorry for the } \\
\text { inconvenience }\end{array}$ \\
\hline sent & $\begin{array}{l}\text { Hey, it's [counselor name] from [program name]. If you haven't completed the FAFSA } \\
\text { application for the 2020-2021 school year, visit www.fafsa.gov. Have your } 2018 \text { income } \\
\text { information ready. Text if you need help or have questions. }\end{array}$ \\
\hline sent & not an inconvenience at all- $\mathrm{i}$ just want to make sure we can get you $\$$ if we can:) \\
\hline received & Called them and everything and they said we're in the good!!! \\
\hline sent & $\begin{array}{l}\text { бت̈ }{ }^{\mathrm{TM}} \mathrm{E} \text {. i will email to set you up with another } \$ \text { to your account. it can only be used for } \\
\text { textbooks along with the } \$ \text { that is in your account already. }\end{array}$ \\
\hline received & That's perfect thank you so much!!! \\
\hline sent & $\begin{array}{l}\text { alright, you are all set with } \$ \text { in your bookstore account. you have until 1/30/20 to spend that } \\
\text { money- please let me know if you have questions:) }\end{array}$ \\
\hline received & How do I access the $\$ ?$ \\
\hline received & $\begin{array}{l}\text { Additionally I have a couple other books that aren't found through the library. How can I use } \\
\text { the money I received towards those? }\end{array}$ \\
\hline sent & $\begin{array}{l}\text { good morning, you can go to the bookstore and get the books that are required for the classes } \\
\text { you are registered for- } \mathrm{i} \text { recommend going to the register on the } 2 \text { nd floor "Dept. Charges" } \\
\text { register and telling them you have an account through [program name] }\end{array}$ \\
\hline sent & $\begin{array}{l}\text { Are you saying that the bookstore doesn't carry some of your textbooks? Or the library at } \\
\text { school? }\end{array}$ \\
\hline received & $\begin{array}{l}\text { Some of the textbooks my classes require is through websites and purchases that aren't } \\
\text { applicable through the library or bookstore }\end{array}$ \\
\hline received & Also is it possible for me to order online? Or do I have to go in myself and get all the books? \\
\hline sent & $\begin{array}{l}\text { yes, you can order online, when you go to payment method choose "scholarship" and then type } \\
\text { [program name] in the notes section. if you don't spend the full } \$ \text { at the bookstore, you and i } \\
\text { can work together to get you reimbursed for the amount you have to pay for the other textbooks } \\
\text { from different websites- it's kind of a pain to pull together the documentation but we can } \\
\text { definitely do that if you don't max out at the bookstore:) }\end{array}$ \\
\hline received & $\begin{array}{l}\text { That's perfect thank you!! As of rn I've spent } \$ \text { and the rest of my books sum up to roughly } \$ \text {, } \\
\text { or somewhere around there. I can just pay off the rest afterwards }\end{array}$ \\
\hline sent & $\begin{array}{l}\text { let me know if you want to do the reimbursement process for any of them:) it's just a lot of } \\
\text { paperwork? }\end{array}$ \\
\hline
\end{tabular}




\begin{tabular}{|c|c|}
\hline received & How long would the reimbursement process take? \\
\hline sent & $\begin{array}{l}\text { once we pull together the documentation and turn it in it only takes a few days to get you a } \\
\text { check }\end{array}$ \\
\hline received & $\begin{array}{l}\text { So if I need those textbooks by Sunday for homework, the reimbursement process will likely } \\
\text { take longer? }\end{array}$ \\
\hline sent & $\begin{array}{l}\text { we will need: } 1 \text {. proof of your class registration (with your name visible). } 2 \text {. proof that the } \\
\text { books/texts are required for the classes you are registered for. } 3 \text {. receipt of cost. } 4 \text {. proof of } \\
\text { payment if your name/billing address isn't on the receipt- this can be a copy of your bank } \\
\text { statement showing the } \$ \text { came from your account- name has to be visible. }\end{array}$ \\
\hline sent & you can send me these documents and i can print off at the office and turn in. \\
\hline sent & $\begin{array}{l}\text { you would need to buy the textbooks first and then you can turn in paperwork to get reimbursed. } \\
\text { does that make sense? }\end{array}$ \\
\hline received & Ohhhh I see \\
\hline received & I'll do that then!! \\
\hline sent & $\begin{array}{l}\text { great! you can email me at [email address] with those documents and I can email you a quick } \\
\text { form to fill out so that we have the mailing address you want the check sent to }\end{array}$ \\
\hline sent & screenshots work fine as attachments for me \\
\hline sent & $\begin{array}{l}\text { hi, it's [counselor name] what is this screen shot from? is this to help know how much credit } \\
\text { you have left for the other books you need to purchase? }\end{array}$ \\
\hline sent & $\begin{array}{l}\text { Hey, it's [counselor name] from [program name] . It's time to fill out the 2020-2021 Application } \\
\text { to receive } \$ \$ \$ \text { for next year- if you haven't already done it }\end{array}$ \\
\hline sent & Watch Facebook Live event on how to fill out the Application \\
\hline received & Can I call you around 2:30? \\
\hline sent & are you free at $3 \mathrm{pm} ?$ \\
\hline received & Yes I will be \\
\hline sent & great! can i give you a call at this number at $3 \mathrm{pm} ?$ \\
\hline received & Yes, sounds perfect \\
\hline sent & $\begin{array}{l}\text { Hey, it's [counselor name] from [program name]. Before adding or dropping a class this } \\
\text { semester make sure to check your school's academic calendar for the add/drop dates- so you } \\
\text { don't get penalized for missing this deadline- And talk to your Academic Advisor before } \\
\text { making a change. }\end{array}$ \\
\hline received & $\begin{array}{l}\text { Hi [counselor name], I'm a little confused about the "Information about the course you would } \\
\text { like to take". Idk what parts to cross out and what parts to respond too }\end{array}$ \\
\hline received & $\begin{array}{l}\text { I've sent you an email that will direct you to the form I just filled out via google docs. Hopefully } \\
\text { that will work!! }\end{array}$ \\
\hline sent & $\begin{array}{l}\text { hey, it's [counselor name] from [program name]. i know it is a long shot. but i will be driving } \\
\text { from [college name] to the state house on feb. } 12 \text { for [program name] day and have room for } \\
\text { some [college name] students ( } 2 \text { to be exact). text back by tomorrow } 10 \text { am if you would like } \\
\text { to go. leave [college name] at 7:45am and be back around } 2 \mathrm{pm} \text {. see your OC from high school. } \\
\text { meet legislators. get a [program name] hoody! }\end{array}$ \\
\hline sent & $\begin{array}{l}\text { Hey, it's [counselor name] from [program name]. Do you feel prepared to take on this semester } \\
\text { and succeed? Reply Yes or No }\end{array}$ \\
\hline sent & $\begin{array}{l}\text { The Student Support Services or Academic Services Office on your campus is also a great } \\
\text { resource for scholarships. }\end{array}$ \\
\hline
\end{tabular}




\begin{tabular}{|c|c|}
\hline received & Yes \\
\hline sent & $\begin{array}{l}\text { Hey, it's [counselor name] from [program name]. Do you feel prepared to take on this semester } \\
\text { and succeed? Reply Yes or No }\end{array}$ \\
\hline sent & That's great! $\ddot{Y}^{\mathrm{TM}} \mathrm{E}$ \\
\hline received & Yes \\
\hline sent & $\begin{array}{l}\text { Hey, it's [counselor name] from [program name]. It's a great idea to check your scholarships } \\
\text { account to make sure you are getting your } \$ 1 / \text { year scholarship for this year and future years. } \\
\text { Text if you have questions. }\end{array}$ \\
\hline sent & $\begin{array}{l}\text { Hey, it's [counselor name] from [program name]. MAJOR Confusion? If you have not declared } \\
\text { a major, no worries, your school is probably offering workshops to help. Your advisor and/or } \\
\text { favorite professors could be a great resource. }\end{array}$ \\
\hline received & $\begin{array}{l}\text { Hi [counselor name], I was wondering when I would be reimbursed for the online courses I } \\
\text { bought? }\end{array}$ \\
\hline sent & $\begin{array}{l}\text { hi, Iâ€ } €^{\mathrm{TM}} \mathrm{m} \text { out of the office for a conference and coming back today. I thought it was all set } \\
\text { through your bookstore account? }\end{array}$ \\
\hline sent & I can look when Iâ€ $€^{\mathrm{TM}} \mathrm{m}$ back in the office tomorrow. \\
\hline received & I didn't receive anything through my bookstore account and thank you!! \\
\hline sent & $\begin{array}{l}\text { hi, itâ } €^{\mathrm{TM}_{S}} \text { [counselor name]. our records show [program name] nailed a check to you on } \\
\text { January } 29 \text { th to this address: }\end{array}$ \\
\hline sent & mailed to [home address]. \\
\hline sent & is that correct? it hasn't been cashed/deposited yet.... \\
\hline received & $\begin{array}{l}\text { I didn't realize they were sending me a check. I'll ask my mom if she had received it in the mail. } \\
\text { Thank you so much again!! }\end{array}$ \\
\hline sent & $\begin{array}{l}\text { sounds good. yes, the reimbursement for what you paid out of pocket, comes in a check directly } \\
\text { to you and that is the address you put on the funding form. i am sorry for not being clearer in } \\
\text { my explanation of how this all works. please keep me posted. }\end{array}$ \\
\hline received & My mom had received the check, just never told me haha. Thank you again [counselor name]! \\
\hline sent & well that's good to hear:). happy it has been found! and that you can put that money in the bank \\
\hline sent & $\begin{array}{l}\text { Hey, it's [counselor name] from [program name]. How are your grades? Are you happy with } \\
\text { them? } \quad \text { Let } \quad \text { us } \quad \text { know } \quad \text { by }\end{array}$ \\
\hline received & I'm doing well right now and I'm happy with my grades. Thanks for checking in! \\
\hline sent & :). happy to hear it! \\
\hline sent & $\begin{array}{l}\text { Hey, [counselor name] from [program name]. It isn't too early to be thinking about summer } \\
\text { plans. Visit the Career Center on your campus to learn about paid summer opportunities or talk } \\
\text { to your professors and older students. Find out what they know. }\end{array}$ \\
\hline sent & $\begin{array}{l}\text { Hey, it's [counselor name] from [program name]. Spring break is right around the corner, yay! } \\
\text { Your school may be offering spring break programs. Check them out. Or picking up some extra } \\
\text { work hours for \$ is a great option, too. }\end{array}$ \\
\hline received & $\begin{array}{l}\text { Hi [counselor name], I had filled out the [program name] for the grant a while back but I was } \\
\text { just recently notified I have additional things to do. I'm confused on how to accomplish those } \\
\text { tasks }\end{array}$ \\
\hline sent & is this what you see in your account: \\
\hline
\end{tabular}




\begin{tabular}{|c|c|}
\hline sent & $\begin{array}{l}\text { Provide us with proof of your US Citizenship status. } \\
\text { If you are an eligible non-citizen, please provide us with a copy of one of the following: Your } \\
\text { Alien Registration Receipt Card OR a copy of your Arrival/Departure Record from the US INS } \\
\text { (I-94 form). }\end{array}$ \\
\hline sent & $\begin{array}{l}\text { i'll be back in the office tomorrow morning. let me know if it would help to find a time to chat } \\
\text { by phone. have a good night:) }\end{array}$ \\
\hline received & $\begin{array}{l}\text { Hey [counselor name], sorry for the late response your message just appeared for me for some } \\
\text { reason. And yes it is asking proof of my citizenship. I'm confused on how/what to do from here. }\end{array}$ \\
\hline sent & good morning. no worries. there is a lot going on right now:). what is your citizenship status? \\
\hline received & I am a US citizen \\
\hline sent & were you born in the US or do you have documentation for your citizenship? \\
\hline received & Is a passport considered documentation? \\
\hline sent & $\begin{array}{l}\text { i'm doing some online research and don't see anything on [college name] SFS website- can you } \\
\text { call or email financial aid and ask? }\end{array}$ \\
\hline sent & you might have to have a birth certificate but not $100 \%$ sure. $i$ think asking SFS is the best route \\
\hline sent & $\begin{array}{l}\text { Hey it's [counselor name] from [program name], I wanted to check in and see how you are } \\
\text { doing. You have a lot of information coming at you and it may feel like it's changing every day. } \\
\text { It's ok to be anxious and confused. Let me know if you need help problem solving. We are here } \\
\text { for you. }\end{array}$ \\
\hline sent & [student name] checking in. a passport is enough! they may just want a picture of it \\
\hline received & Alright thank you so much!! \\
\hline sent & $\begin{array}{l}\text { Hey, it's [counselor name] from [program name]. Sending this message in case you or anyone } \\
\text { you know has federal student loans. Federal student loan payments suspended and interest } \\
\text { waived during corona-virus: }\end{array}$ \\
\hline sent & $\begin{array}{l}\text { Good morning first_namexâ€<, it's [counselor name] from [program name] again. Are you } \\
\text { struggling with internet access or do you know someone who is? Here is a map to show you } \\
\text { places you can access WiFi around the state. As always, text if you have questions or need help } \\
\text { finding resources. I am in fact a human and not a robot and am here to help:) }\end{array}$ \\
\hline sent & hey- i meant to say hello to you in the first message. sorry about that:) \\
\hline sent & $\begin{array}{l}\text { Hey, it's [counselor name] from [program name]. Need a summer class to help you stay on } \\
\text { track? Let us know, [program name] can help with summer funding } \$ \$ \text {. }\end{array}$ \\
\hline received & Hi [counselor name], I was wondering what time I'm registered for to sign up for classes \\
\hline sent & $\begin{array}{l}\text { hey, sorry for the delay in getting back to you. did you mean to text me or someone else at } \\
\text { [college name]? }\end{array}$ \\
\hline received & Yeah, it was meant for SSS for my early registration. Sorry about that \\
\hline sent & $\begin{array}{l}\text { Hey, it's [counselor name] from [program name] again. With all that's going on, we just want } \\
\text { you to know that we are here to be a problem solving partner. TEXT back if you need help } \\
\text { finding resources around: food, housing, technology, education related needs, etc..... }\end{array}$ \\
\hline sent & $\begin{array}{l}\text { Hey, it's [counselor name] from [program name]. Do you need help with emergency funding } \\
\text { related to COVID 19? Housing, Technology, Food, Healthcare, etc. }\end{array}$ \\
\hline
\end{tabular}




\begin{tabular}{|c|c|}
\hline sent & $\begin{array}{l}\text { Here } \\
\text { 1. contact your school's financial aid office and ask about }\end{array}$ \\
\hline sent & $\begin{array}{l}\text { Hey, it's [counselor name] from [program name]. We know a lot happened this spring that } \\
\text { couldn't be planned for. Have your financial circumstances changed since renewing your } \\
\text { FAFSA. Text back. We are here to help. Here are some resources for you if needed: }\end{array}$ \\
\hline sent & 1. An online tool to appeal your school's financial aid award offer: \\
\hline sent & $\begin{array}{l}\text { Hey, it's [counselor name] from [program name]. Moving to online may have been a big } \\
\text { transition for you. Was your academic performance affected by all that happened around } \\
\text { COVID? Text back "yes" or "no" }\end{array}$ \\
\hline sent & $\begin{array}{l}\text { Hey, it's [counselor name] from [program name]. We wanted to check and see if your plans for } \\
\text { next year have changed. Are you thinking of transferring? }\end{array}$ \\
\hline received & I'm planning on staying at [college name] \\
\hline sent & $\begin{array}{l}\text { Hopefully that means you are happy where you areðŸ } \check{Y}^{\sim} \text {. You don't have to do anything. Your } \\
\text { scholarship auto-renews if you stay at the same school. }\end{array}$ \\
\hline sent & $\begin{array}{l}\text { Hi, this is [counselor name] from [program name]. I want to ask you a few short questions to } \\
\text { learn how to do a better job of helping first year students. If you answer all of them (within } 24 \\
\text { hours) I will enter your name into a drawing for \$ toward textbooks. Text YES to participate. }\end{array}$ \\
\hline sent & $\begin{array}{l}\text { How many of the books required for your SPRING classes did you buy/rent? Text back A (all), } \\
\mathrm{S} \text { (some), or N (none). }\end{array}$ \\
\hline received & Yes \\
\hline sent & Please text a 1-2 sentence summary of your book buying decisions. \\
\hline received & $\mathrm{S}$ \\
\hline received & I purchased all the books that I knew were going to be essential for the semester \\
\hline sent & $\begin{array}{l}\text { Have you spoken with someone in your college's financial aid office (in person or on the } \\
\text { phone)? Text back Y (yes) or N (no). }\end{array}$ \\
\hline sent & Text a 1-2 sentence summary of your experience with the financial aid office. \\
\hline received & $\mathrm{Y}$ \\
\hline sent & $\begin{array}{l}\text { Did you ever go to the Academic Support Services or Student Support Services office? (You } \\
\text { may have gone for tutoring, FAFSA renewal help, to drop in for food, etc.) Text Y (yes), N } \\
\text { (no), or U (unsure). }\end{array}$ \\
\hline received & Very helpful and informative when it came to the information they provided \\
\hline received & $\mathrm{U}$ \\
\hline sent & Text us a 1-2 sentence summary where you got help/support this year. \\
\hline received & I've dropped in for FAFSA help \\
\hline sent & What is a lesson you learned this year that you wish you knew before starting college? \\
\hline
\end{tabular}




\begin{tabular}{|l|l|}
\hline sent & Last question: How have your plans for next year been affected by the COVID-19 pandemic? \\
\hline received & Manage your time wisely \\
\hline received & Nothing drastic, still planning on attending and living on campus at [college name] \\
\hline sent & $\begin{array}{l}\text { Thank you for answering my questions! Your name is in the drawing for \$ book money, and I } \\
\text { will contact the winner by July 1. [program name] staff are always available to help. }\end{array}$ \\
\hline sent & $\begin{array}{l}\text { Hi There's still time to finish the survey and be entered into the drawing. Text back YES to } \\
\text { pick up where you left off! }\end{array}$ \\
\hline
\end{tabular}

Real names were changed. Also, phone numbers and email addresses were altered to protect identities of student and program staff 